\title{
Impact of Positive Selection on Incidence of Different Viruses During Multiple Generations of Potato Seed Tubers in Uganda
}

\author{
Uta Priegnitz $^{1}$ (D) Willemien J.M. Lommen ${ }^{1}$. \\ René A.A. van der Vlugt ${ }^{2}$ - Paul C. Struik ${ }^{1}$
}

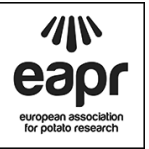

Received: 20 December 2017 / Accepted: 5 July 2018 /

Published online: 21 September 2018

(C) The Author(s) 2018

\begin{abstract}
Smallholder farmers in Uganda commonly use seed potato tubers from the informal sector, especially by seed recycling over several generations. Therefore, seed tubers are highly degenerated with viruses and other pathogens, resulting in poor yield and quality of the produce. Over one cycle of multiplication, degeneration management by positive seed selection was found to be efficient in reducing virus diseases compared with the farmers' method of selection. The objective of this study was to assess to what extent positive selection over several seasons can reduce six different virus incidences in seed lots of different starting quality in southwestern Uganda. Multi-seasonal trials were carried out in three locations, with five seed lots from four sources and three cultivars. Detection of viruses was based on DAS-ELISA and Luminex xMAP technology. Analysis was carried out with analysis of variance (ANOVA) on angulartransformed percentages of virus incidence. Results showed fluctuations in some viruses over seasons with lower Potato leafroll virus (PLRV) and Potato virus $X$ (PVX) incidences in lots from positive selection compared with lots from farmers' selection. In contrast, some seed lots were initially highly infected with Potato virus $S$ (PVS) and Potato virus $M(\mathrm{PVM})$ and showed no reduction in virus incidence through positive selection. In general, little infection with Potato virus $Y$ (PVY) and Potato virus A (PVA) was found. Based on these results, it is recommended that smallholder farmers are trained in positive selection to opt for less virus-infected plants and tubers, thus increasing potato production.
\end{abstract}

Uta Priegnitz

uta.priegnitz@wur.nl

1 Centre for Crop Systems Analysis, Wageningen University and Research, P.O. Box 430, 6700 AK Wageningen, The Netherlands

2 Biointeractions and Plant Health, Wageningen Plant Research, P.O. Box 16, 6700 AA Wageningen, The Netherlands 
Keywords Multi-seasonal trials · Positive selection - Seed degeneration - Seed potatoes · Seed regeneration $\cdot$ Uganda $\cdot$ Viruses

\section{Introduction}

In Uganda, potato is an important food and cash crop for farmers. However, low productivity of the crop associated with poor quality of harvested tubers is a major concern. Potatoes are vegetatively propagated by means of tubers, called seed tubers, from the harvest of a seed potato crop or selected from the harvest of a ware potato stock. Final yield and tuber quality of ware potatoes depend on the quality of the planted seed tubers (Struik and Wiersema 1999). Poor seed tuber quality is a major production constraint, especially in Eastern Africa, including Uganda (Gildemacher et al. 2009; Thomas-Sharma et al. 2016). Farmers in Uganda have poor or no access to high-quality seed and commonly use their own recycled seed potatoes, or seed tubers from the informal sector, including the local market, family, or neighbours (Gildemacher et al. 2009; International Potato Center 2011). Farmers generally select seed tubers from the bulk of the potato harvest based on seed size and visual inspection; this method is further referred to as farmers' selection.

Degeneration of seed potatoes can be defined as a decline in seed potato quality by a build-up of pathogens and pests over subsequent generations and is primarily caused by viruses (Loebenstein and Gaba 2012; Thomas-Sharma et al. 2016). It occurs when seed tubers are recycled for several subsequent field generations under conditions that are conducive to (re-)infection. Incidence of potato viruses in potato seed tubers can be high, and these viruses can significantly reduce seed tuber health status (Salazar 1996; Kinyua et al. 2012). Substantial yield reductions with Potato leaf roll virus (PLRV) of up to $90 \%$ have been reported (Jeffries, 1998; Guzmán-Barney et al. 2012). According to Fuglie (2007), especially PLRV, Potato virus $Y$ (PVY), and Potato virus X (PVX) cause severe yield and quality losses for potato farmers in Sub-Saharan Africa.

In general, two ways of virus infection are taking place: primary virus infection and secondary virus infection. Primary virus infection occurs when a healthy potato plant becomes infected with a virus. The virus multiplies in the plant, and virus particles systemically translocate to the tubers. Secondary infection occurs when infected daughter tubers are planted as seed, and therefore the plant and the next generation of tubers become infected, albeit not always for the full $100 \%$ (Bertschinger et al. 2017).

Primary infection can only occur through transmission of virus. Aphids are the main vectors spreading virus diseases like PLRV and Potato virus A (PVA), whereas PVX is only transmitted mechanically. PVY, Potato virus $S$ (PVS), and Potato virus $M$ (PVM) can be transmitted in both ways (de Bokx and van der Want 1987; Salazar 1996; Struik and Wiersema 1999).

In general, PLRV and PVX infections show severe visual symptoms (upward rolling of leaflets for PLRV; stunting, mosaic patterns on leaflets for both PLRV and PVX), PVY and PVA infections show mild visual symptoms (mild mosaic, tip necrosis), and PVS and PVM infections are usually symptomless (Loebenstein et al. 2001). However, visual symptoms can vary depending on cultivar, virus strain, synergisms in mixed infections, and environmental conditions (Döring 2011). 
To overcome the existing constraint of poor seed quality in Eastern Africa, a seed degeneration management technology, known as positive selection, was found to be highly effective in increasing the low tuber yield; this technology was associated with reduced virus incidence for PLRV, PVX, and PVY (Gildemacher et al. 2011; Schulte-Geldermann et al. 2012). When carrying out positive selection, the healthiest looking plants in ware potato crops are pegged and selected just before full flowering to identify plants of which tubers will serve as seed for the next season (Gildemacher et al. 2007). Two weeks after selecting, the positive-selected plants have to be checked for being still without symptoms. At harvest, tubers from selected plants are separately collected from those of nonselected plants and used in the next season as seed tubers for the next crop, after checking their health status visually and selecting the appropriate size. In this way, the best looking tubers from the healthiest looking plants are planted in the next season and are expected to produce relatively healthy plants and progeny tubers, with reduced virus infection and increased yield potential compared with standard farmers' procedures of seed selection (Schulte-Geldermann et al. 2012).

To the best of our knowledge, until now, literature reports on positive seed selection were limited to investigations including only one growing cycle of multiplication and three viruses (PLRV, PVX, PVY). The current research focuses on examining and understanding positive selection for maintaining quality of the seed potato stock, with regeneration across multiple cycles, for six viruses (PLRV, PVX, PVY, PVA, PVS, and PVM) differing in severity of symptoms and method of transmission. Different locations of seed production, various sources of seed, and different cultivars were included in the field experiments.

The objectives of this study were to analyse how the incidence of contrasting viruses across several seasons of multiplication changes using different seed selection methods (positive selection, farmers' selection) under the climatic conditions in southwestern Uganda and in seed lots from different origin and starting quality. Specific research questions were (1) whether positive selection across several field generations could lead to a reduction in virus infection (regeneration) in different seed lots; (2) whether positive selection could maintain a high health status of tubers when healthy $3 \mathrm{G}^{1}$ seed tubers from the national Ugandan research station are used; and (3) whether seeds from positive selection have a reduced virus incidence compared to those from farmers' selection. Knowledge acquired in this research can contribute to a deeper understanding of the dynamics of viral diseases in the potato crop and of the role of positive selection in reducing seed degeneration. Such knowledge could also help to sustainably improve the availability of high-quality seed tubers in Uganda and other East African countries by own-produced seed. It could also help to design alternative seed systems suitable for low-income countries with limited opportunities to implement strict seed certification schemes.

\footnotetext{
${ }^{1} 3 \mathrm{G}$ seed (also called Basic Seed) refers to three generations of multiplying, starting from in-vitro culture and, thereafter, being multiplied in the greenhouse and in the field. Currently, $3 \mathrm{G}$ seed can be purchased from the research institute KAZARDI in Uganda.
} 


\section{Materials and Methods}

\section{Experimental Design}

Three multi-season field experiments were carried out across four production seasons at three locations in Kabale district in the main potato production region of southwestern Uganda. Details of all locations and experiments are presented in Table 1. For the first two experiments, two high-quality $3 \mathrm{G}$ seed tuber lots were obtained from the Kachwekano Zonal Agricultural Research and Development Institute (KAZARDI), one seed tuber lot from cv. Victoria and one seed tuber lot from cv. Katchpot 1. Experiment 1, with both seed lots, was planted in the fields of the research station KAZARDI located in Karengyere (2433 m asl); Experiment 2, with the same seed lots, was planted in the fields of the research station in Kabale (2246 m asl). In Experiment 3, three seed sources were used: (a) 4G seed potatoes of cv. Victoria from the Ugandan National Seed Potato Production Association (UNSPPA); (b) seed potatoes of cv. Victoria from the local market (unknown generation); and (c) 5G seed potatoes of cv. Rwangume from a local farm which saved seed potatoes for own use. Experiment 3, with these three seed sources, was planted in the fields of a local farm in Hamurwa (2220 m asl).

Planting took place in four subsequent seasons: October 2013 (1st season 2013 long rainy season (LRS)), April 2014 (2nd season 2014 short rainy season (SRS)), October 2014 (3rd season 2014-LRS), and April 2015 (4th season 2015-SRS). Two growing seasons in one calendar year were used because of the two rainy seasons (LRS and SRS) in this region and because planting potato in both seasons is a common practice in Kabale district (Gildemacher et al. 2009).

The experiments had a split-plot design with the seed potato lot as main factor and the seed selection method as a sub factor in three replicated blocks. In the experiments, four seed selection methods were applied: (a) positive selection (PS) in all seasons (further referred to as PS-PS-PS), (b) farmers' selection (FS) in all seasons (further referred to as FS-FS-FS), (c) alternating seed selection in the seasons starting with positive selection in the 1st season (further referred to as PS-FS-PS), and (d) alternating seed selection in the seasons starting with farmers' selection in the 1st season (further referred to as FS-PS-FS) (Fig. 1). The 4th season is lacking in these codes because that season was used to assess the quality of the tubers produced in the previous seasons. Because some treatments only started to differ later in the 2nd season, the data on the 1 st season presented in Table 2 are based on the double number of plots.

In one gross experimental plot, 60 tubers were planted in six rows with a row spacing of $70 \mathrm{~cm}$ and a seed spacing within the row of $30 \mathrm{~cm}$; for the net plot, the border plants in the outer rows were excluded, so in total 40 tubers or plants in the net plot were used for the assessment. In the PS treatment, 15 plants from the 40 tubers in the net plot were selected for positive selection, which accounts for plants from $37.5 \%$ of all seed tubers planted in the net plot. The harvest of those 15 plants was needed to achieve enough medium-sized seed potatoes for the next planting season under the conditions in Kabale district in southwestern Uganda. Under PS, the 15 best looking plants in the plot were selected just before full flowering (65-73 DAP), and those plants were checked again 2 weeks later (Table 1). In the FS plots, plants were not selected during crop growth and medium-sized seed tubers were selected by farmers at planting 


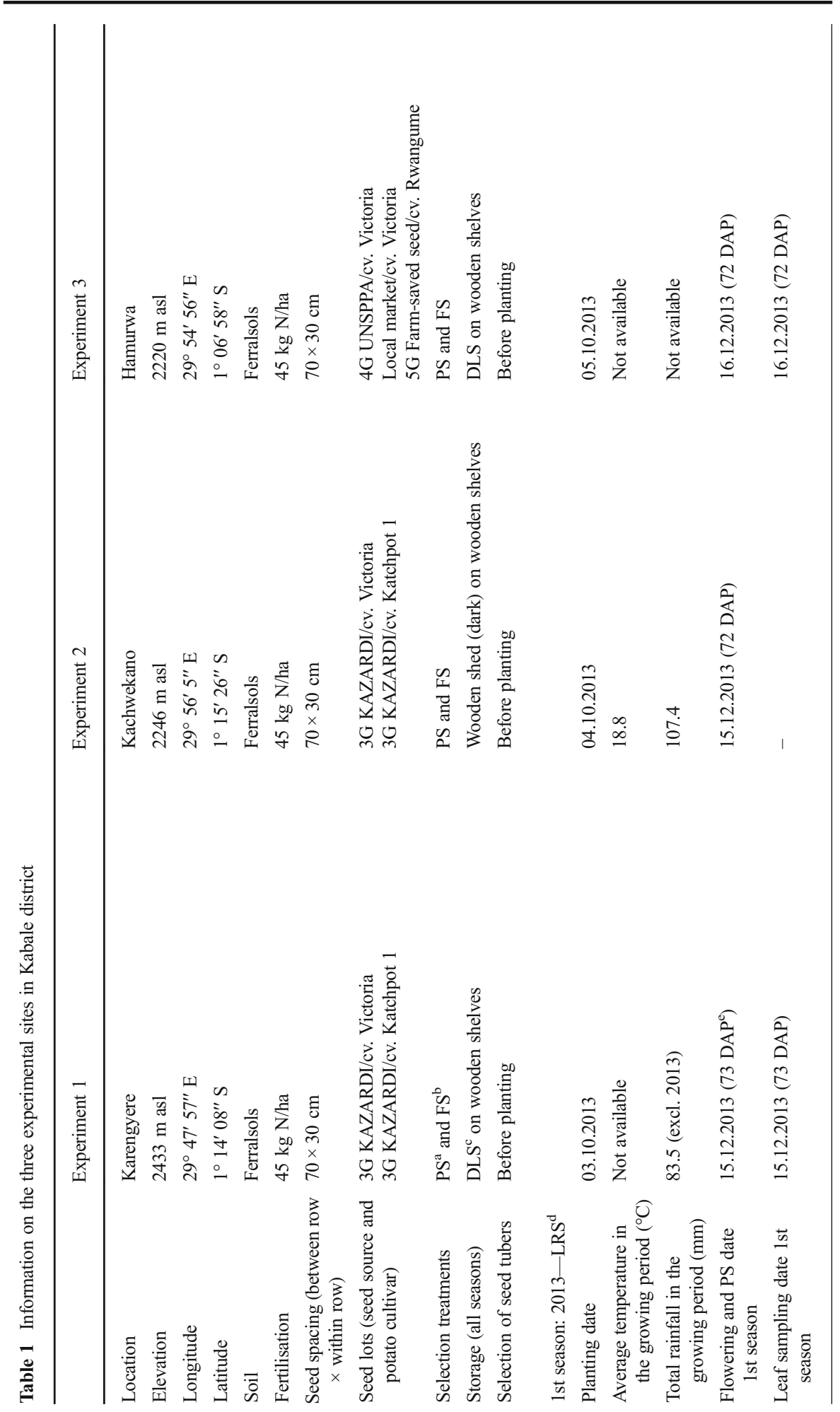




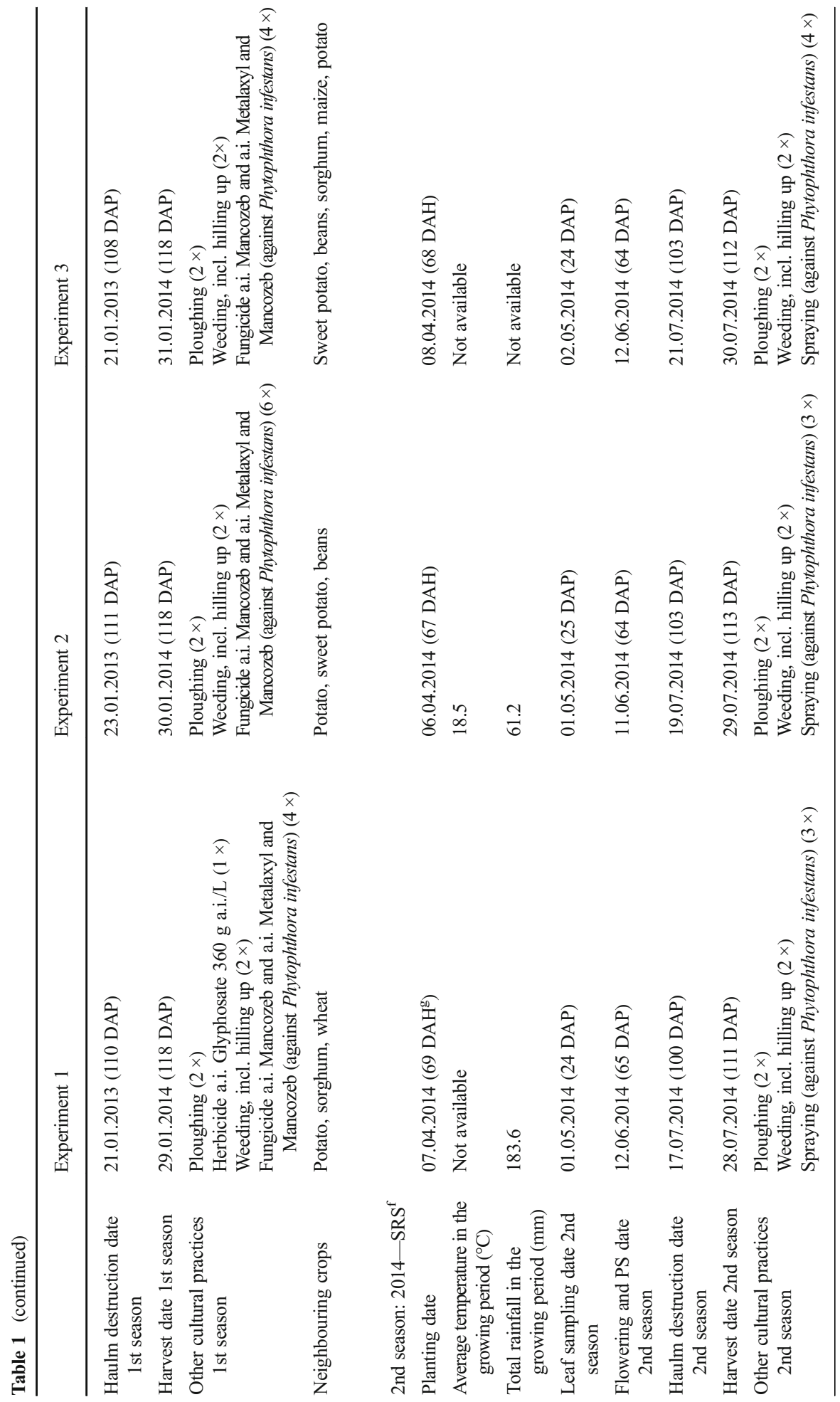




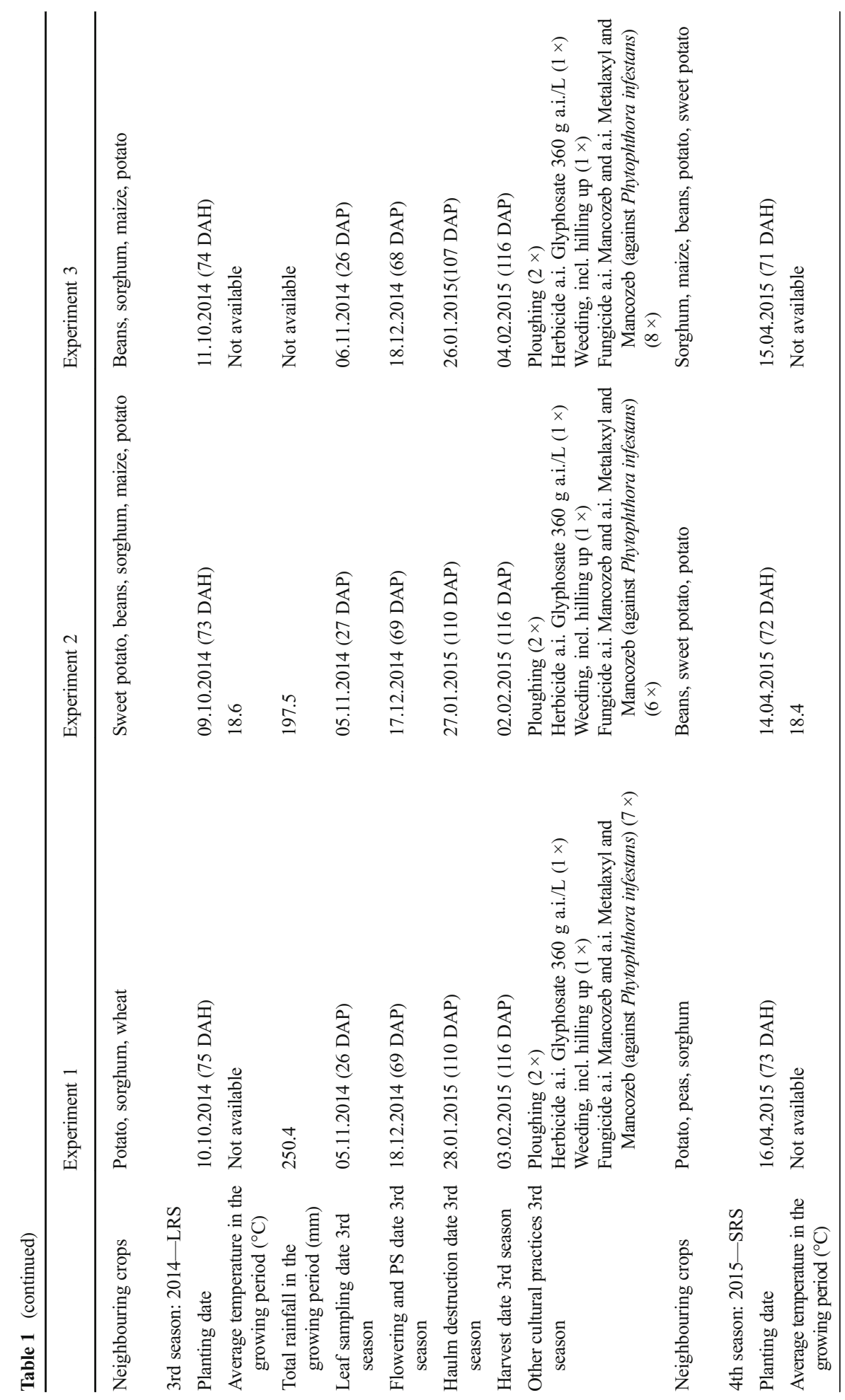




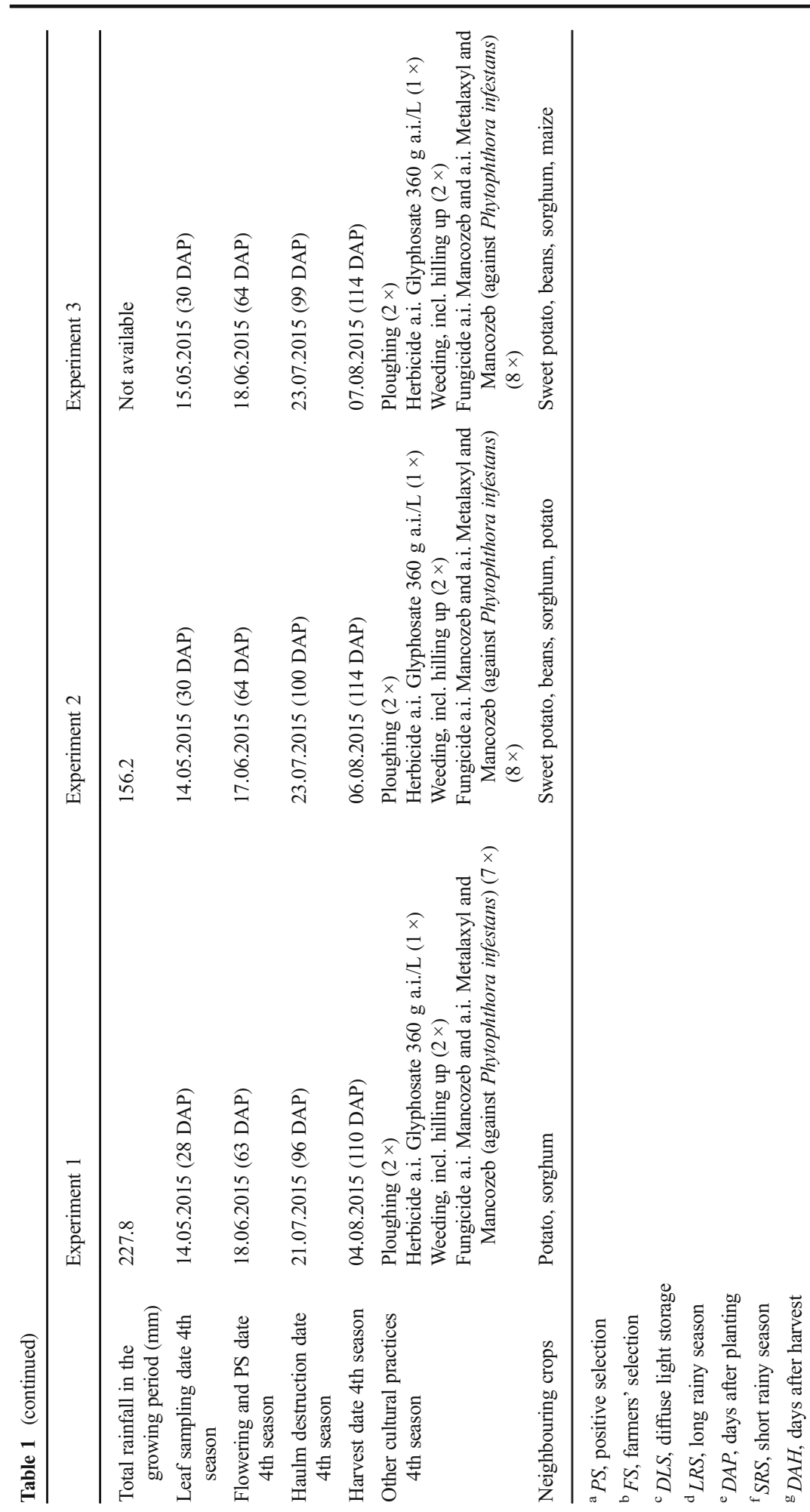




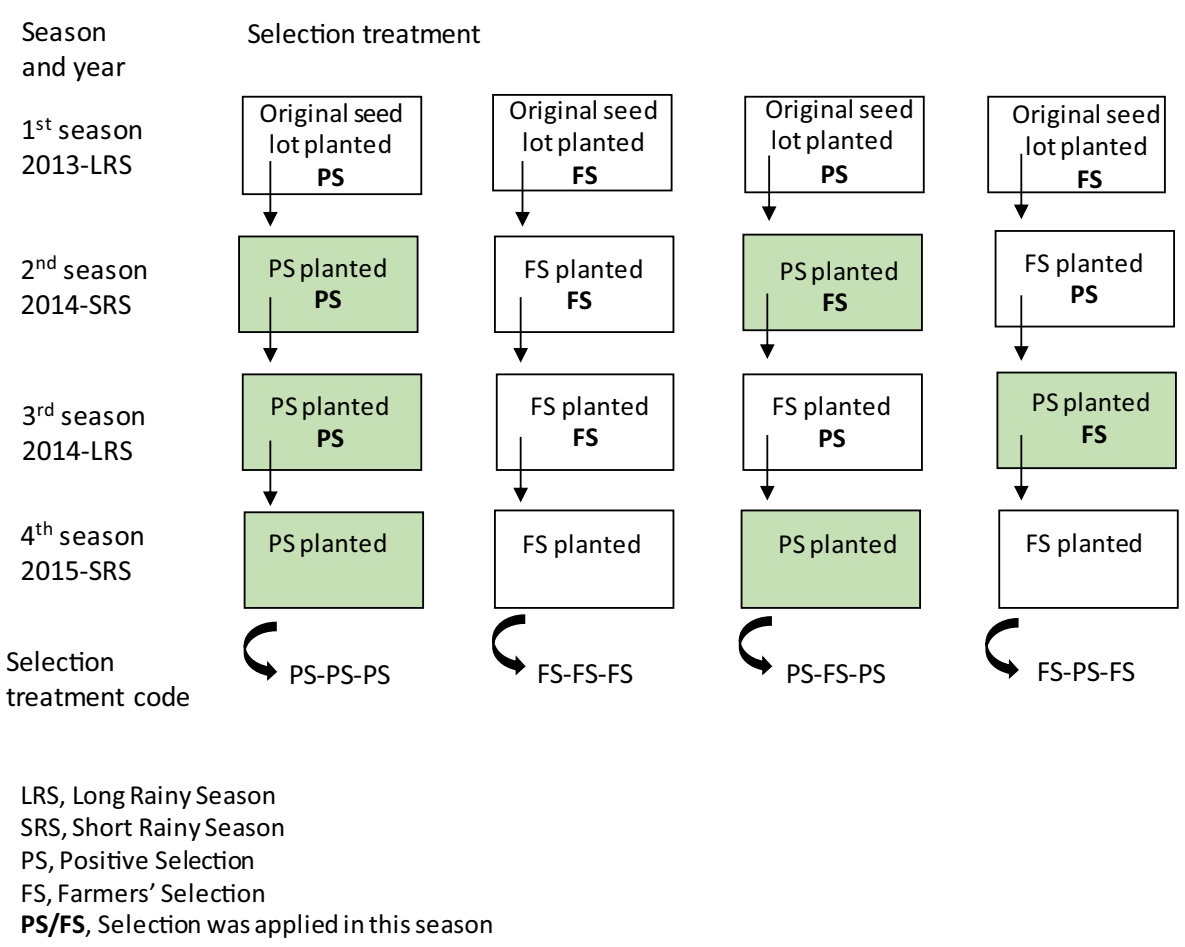

Fig. 1 Scheme of selection treatments (in green when positive selection seed was planted) in the three experiments over the seasons

time from the stored tuber bulk of the former harvest. In the PS treatments, plants were selected during crop growth and seed tuber selection was done by farmers at planting time by selecting medium-sized seed tubers from the stored PS-plants tubers. For each of the four treatments, the replicated plots were combined before selecting the seed tubers.

Fertilisation was done with $45 \mathrm{~kg} \mathrm{~N} /$ ha at planting in each season, based on NPK 17:17:17, and further crop management was done according to general recommendations to farmers (Table 1).

\section{Sampling Method of Plants and Tubers for Virus Testing}

To assess the virus incidence in the crops grown from the original seed lots and to assess the virus incidence in the plants selected for positive selection, leaves were sampled in the 1 st season in Experiments 1 and $3^{2}$ on the day of PS, which was just before full flowering. In the plots receiving positive selection, leaves were sampled from 10 of the 15 positive selected plants. For the plots where no selection took place (FS plots), samples were taken from 10 random plants per net plot. These samples represent the virus status of the crops from the original seed lot and the virus status of the plants used for FS and PS.

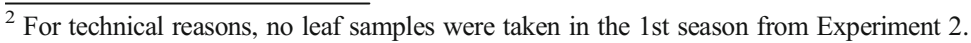




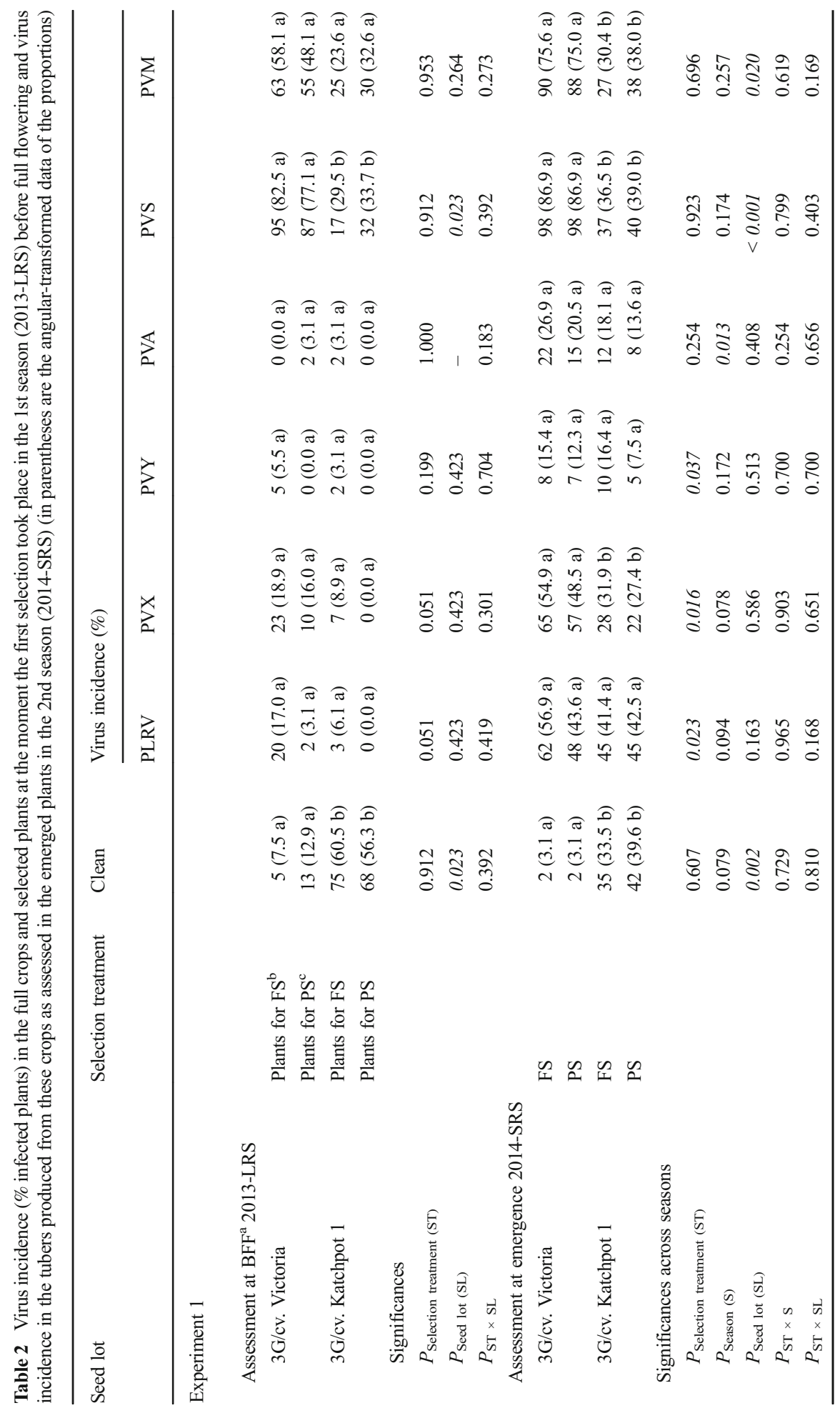




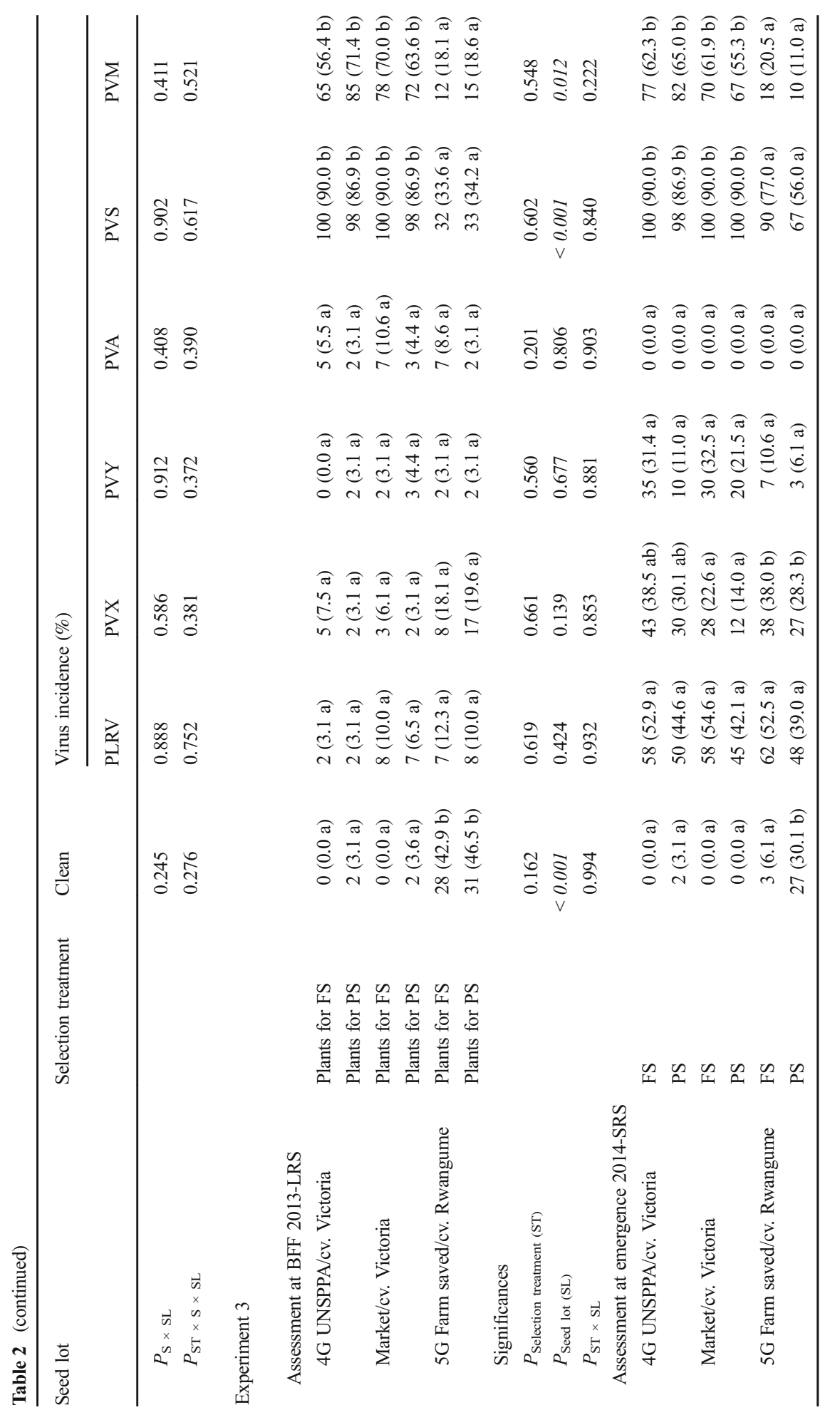




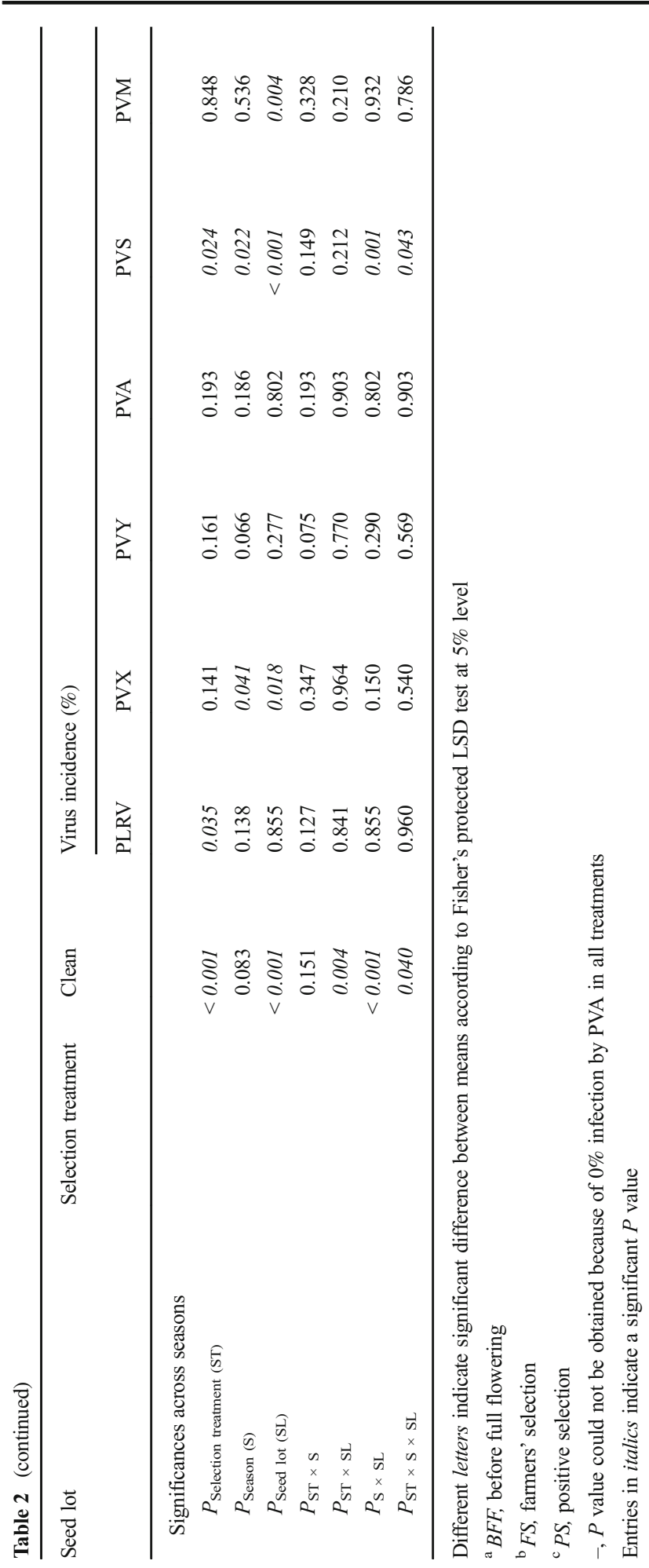


To determine the virus status of the tubers produced in the different treatments during the $1 \mathrm{st}, 2 \mathrm{nd}$, and $3 \mathrm{rd}$ seasons, leaf samples of 10 plants were taken in each net plot from the newly emerged plants from these tubers in the 2nd, 3rd, and 4th season, respectively, when plantlets were approximately $15 \mathrm{~cm}$ tall (24 to 30 DAP; Table 1 ).

The leaf sample per plant consisted of three leaflets, one from each of the upper three leaves. Those three leaflets were combined in one sampling bag. All leaf samples were transported by airplane in a cardboard box to the Netherlands within 2 days, stored at $-80{ }^{\circ} \mathrm{C}$ and analysed for virus infection at the end of the experiments. All leaf samples were destroyed after analyses were concluded.

\section{Assessing Virus Infection}

To assess the virus incidence in crops and PS selected plants from the original seed lots in the 1st season, the infection by PLRV, PVX, PVY, PVA, PVS, and PVM in each of 10 plants per plot was assessed with DAS-ELISA according to a standard protocol (Prime Diagnostics) with polyclonal antibodies obtained from Prime Diagnostics ${ }^{\circledR}$ (Primediagnostics 2013).

To assess the virus incidence in the seed tubers produced in a season, leaves from 10 newly emerged (in the next season) plants per net plot were assessed with the Luminex xMAP technology (van der Vlugt et al. 2015) according to the standard protocol (Primediagnostics 2013). Samples were tested for six potato viruses PLRV, PVX, PVY, PVA, PVS, and PVM simultaneously with a Luminex xMAP kit based on DAS-ELISA polyclonal antibodies supplied by Prime Diagnostics® (Primediagnostics 2013). Samples were considered virus-positive when values for optical density at $405 \mathrm{~nm}$ (OD 405) in ELISA or XMAP Mean Fluorescent Intensities (MFIs) were higher than the total of the average of six negative controls plus three times the standard deviation of the negative controls.

We compared DAS-ELISA and Luminex in numerous samples, and the two methods produced the same results and showed the same sensitivity.

If a sample was free of the viruses tested, this plant was considered clean.

\section{Haulm Removal, Tuber Harvest and Tuber Storage}

Haulm removal was done manually between 96 to 111 days after planting when plants had reached final maturity (Table 1). At harvest, between 111 to 118 days after planting (Table 1), all tubers from the selected plants in plots receiving PS were separately harvested. During storage, the individual replicates of one treatment were combined and stored separately from the tubers of the other treatments. In plots receiving FS in a given season, all tubers were harvested.

All tubers were stored on wooden shelves either in a dark wooden shed (Experiment 2) or in diffuse light storage (Experiments 1 and 3), all with insecticide a.i. Malathion 57\% sprinkled on top and covered with grass locally called "Kikuyu" (Pennisetum clandestinum) and couch grass (Digitaria abyssinica). Storage duration of the tubers was between 69 and 75 days (Table 1$)$.

\section{Monitoring Aphid Abundance and Weather Data}

To monitor aphid pressure, three yellow water traps were placed in the middle of each of the three blocks in each experiment in Seasons 2 to 4 . Rectangular yellow plastic 
traps $(35.0 \mathrm{~cm} \times 25.0 \mathrm{~cm} \times 8.0 \mathrm{~cm}, l \times w \times h)$ were filled to two thirds with tap water and a small amount of dish washer detergent added to decrease surface tension. Traps were installed in the fields after sampling of the leaves of the emerged plants in order to avoid possible early attraction and influx of aphids. Aphids were collected weekly and counted, but no distinction was made between species (Fig. 2).
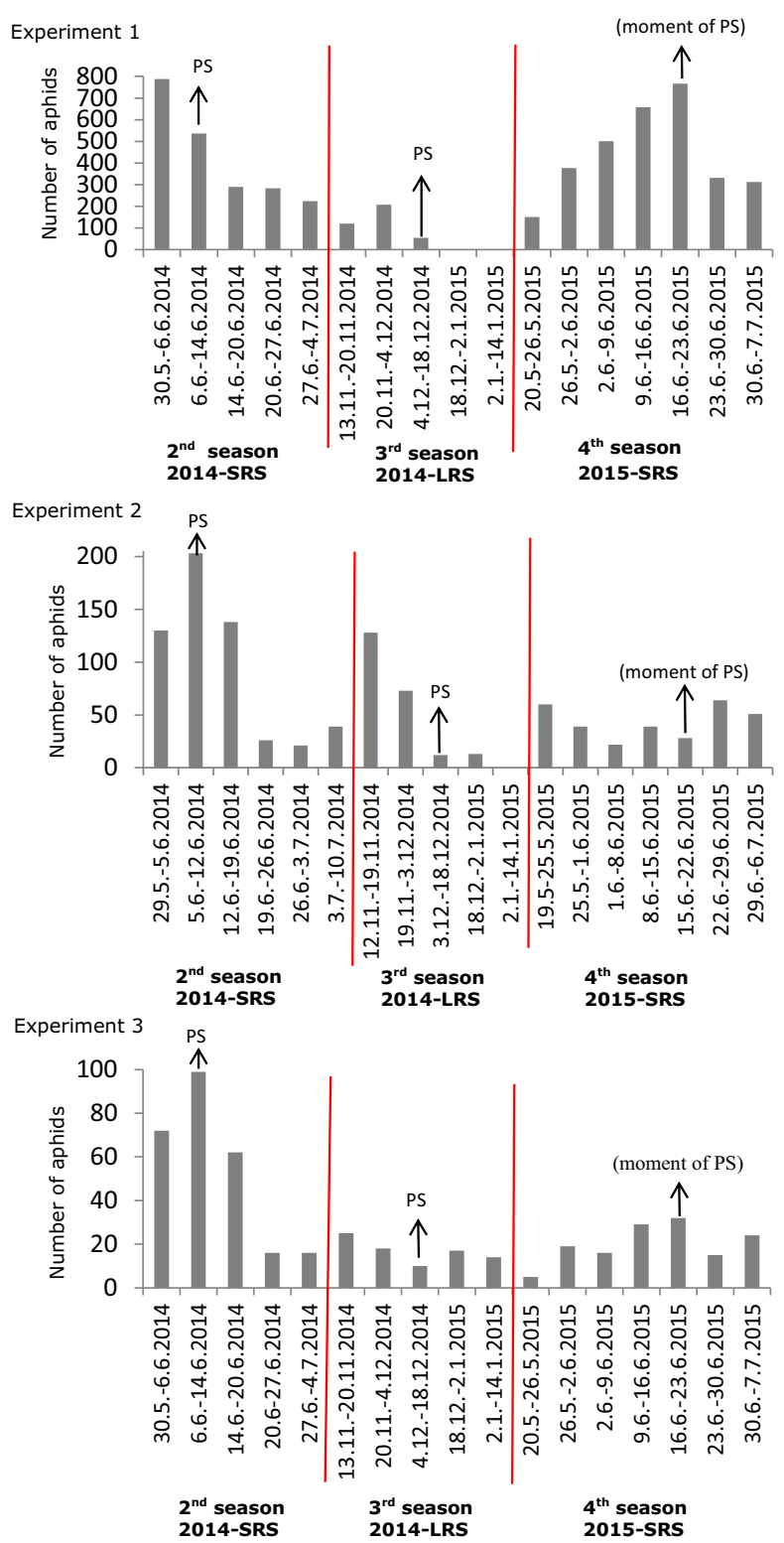

Fig. 2 Seasonal aphid catches during three experimental periods (growing period 2nd season 2014-SRS, 3rd season 2014-LRS, and 4th season 2015-SRS) (red lines indicate the next growing period). Aphid data were not recorded in the 1 st season 
Weather data were derived from the internet platform aWhere (2016) for Experiment 2 (Fig. 3); for Experiment 1, manually monitored rain data were recorded at the KAZARDI station in Karengyere (Table 1). No reliable weather data were available for Experiment 3.

\section{Statistical Analysis}

Data were analysed using GenStat for Windows 18th Edition (VSN International 2016). General Analysis of Variance was used to test the effect of the factors selection method, season, and seed lot and their interactions on incidence of the individual viruses and the proportion of plants free of virus. Angular transformations of proportions were made before analysis (Fernandez 1992). When proportions were equal to 0 or 1 , a replacement was done by $(1 / 4 n)$ and $[1-(1 / 4 n)]$, respectively, where $n$ represents the total number of leaf samples per net plot (Fernandez 1992). The data from the plants and tubers produced in the first season (Table 2) had double the number of plots for treatments because the two alternating treatments (PS-FS-PS and FS-PS-FS) only started to differ from the two consistent treatments (PS-PS-PS and FSFS-FS) from the end of the second season onwards. In the analysis, contrasts between the four selection treatments across multiple seasons were used to test for differences between individual selection treatments. Where the $P$ value in the ANOVA showed significant effects or interactions $(P<0.05)$, Fisher's protected least significant difference (LSD) test at $\alpha=0.05$ was applied.

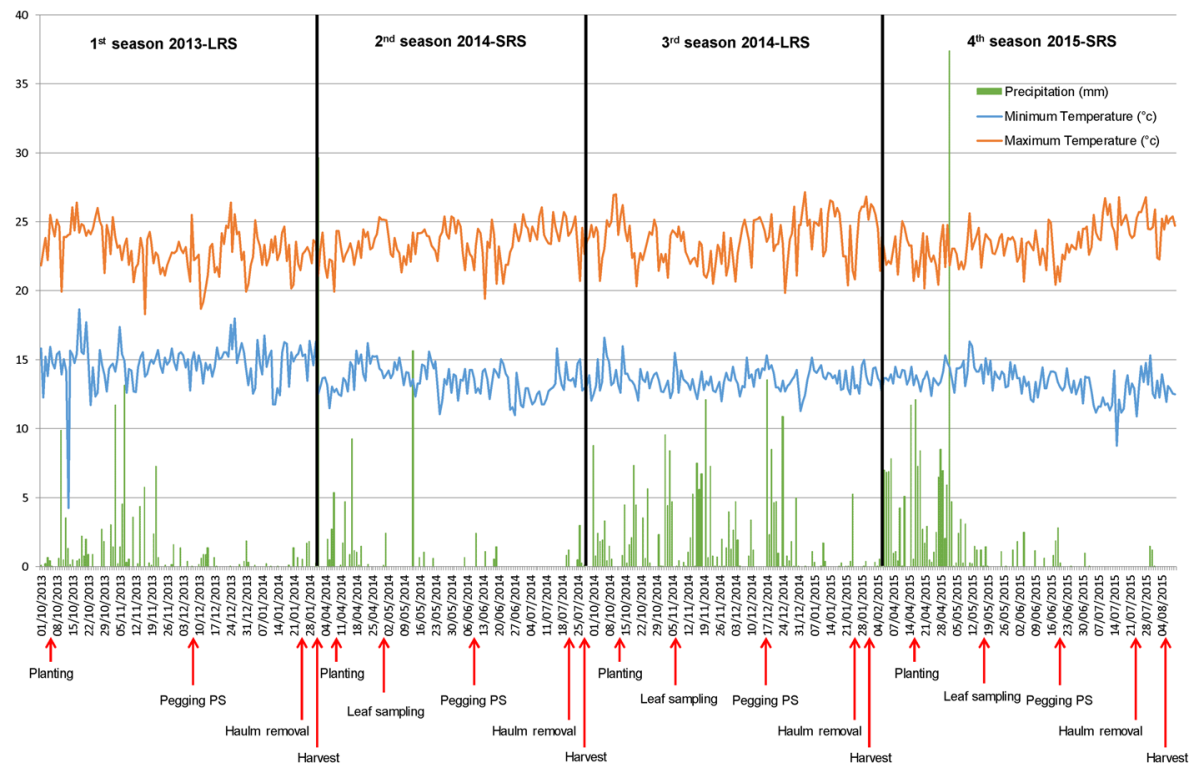

Fig. 3 Weather data of Experiment 2 during the growing periods with important crop and experiment management practices (black lines indicate the next season) 
Table $3 P$ values of the $F$ ratios from ANOVA for the effects of selection treatment, season, and seed lot and their interactions in the three experiments

Factors and contrasts

Clean Virus

PLRV PVX PVY PVA PVS PVM

Experiment 1

Selection treatment

PS-PS-PS vs FS-FS-FS

PS-PS-PS vs PS-FS-PS

PS-PS-PS vs FS-PS-FS

PS-FS-PS vs FS-FS-FS

PS-FS-PS vs FS-PS-FS

FS-PS-FS vs FS-FS-FS

Season

Linear change season

Seed lot

Selection treatment $\times$ season

PS-PS-PS vs FS-FS-FS $\times$ linear season

PS-PS-PS vs PS-FS-PS $\times$ linear season

PS-PS-PS vs FS-PS-FS $\times$ linear season

PS-FS-PS vs FS-FS-FS $\times$ linear season

PS-FS-PS vs FS-PS-FS $\times$ linear season

FS-PS-FS vs FS-FS-FS $\times$ linear season

Selection treatment $\times$ seed lot

PS-PS-PS vs FS-FS-FS $\times$ seed lot

PS-PS-PS vs PS-FS-PS $\times$ seed lot

PS-PS-PS vs FS-PS-FS $\times$ seed lot

PS-FS-PS vs FS-FS-FS $\times$ seed lot

PS-FS-PS vs FS-PS-FS $\times$ seed lot

FS-PS-FS vs FS-FS-FS $\times$ seed lot

Season $\times$ seed lot

Linear season $\times$ seed lot

Selection treatment $\times$ season $\times$ seed lot

PS-PS_PS vs FS-FS-FS $\times$ linear season $\times$ seed lot 0.660

PS-PS-PS vs PS-FS-PS $\times$ linear season $\times$ seed lot 0.398

PS-PS-PS vs FS-PS-FS $\times$ linear season $\times$ seed lot 0.649

PS-FS-PS vs FS-FS-FS $\times$ linear season $\times$ seed lot 0.683

PS-FS-PS vs FS-PS-FS $\times$ linear season $\times$ seed lot 0.635

FS-PS-FS vs FS-FS-FS $\times$ linear season $\times$ seed lot 0.988

$\begin{array}{lllllll}0.305 & 0.137 & 0.018 & 0.131 & 0.025 & 0.999 & 0.993 \\ 0.084 & 0.037 & 0.009 & 0.040 & 0.046 & 0.972 & 0.958 \\ 0.128 & 0.121 & 0.011 & 0.322 & 0.659 & 0.987 & 0.891 \\ 0.293 & 0.053 & 0.007 & 0.050 & 0.008 & 0.910 & 0.884 \\ 0.827 & 0.563 & 0.923 & 0.267 & 0.113 & 0.958 & 0.850 \\ 0.627 & 0.684 & 0.856 & 0.312 & 0.024 & 0.896 & 0.777 \\ 0.482 & 0.863 & 0.923 & 0.920 & 0.468 & 0.938 & 0.925 \\ 0.751 & 0.458 & 0.607 & 0.172 & 0.006 & 0.033 & 0.154 \\ 0.895 & 0.576 & 0.636 & 0.662 & 0.035 & 0.023 & 0.136 \\ <0.001 & 0.200 & 0.004 & 0.749 & 0.281 & <0.001 & <0.001 \\ 0.150 & 0.736 & 0.965 & 0.912 & 0.232 & 0.160 & 0.376 \\ 0.444 & 0.983 & 0.803 & 0.868 & 0.428 & 0.236 & 0.068 \\ 0.248 & 0.897 & 0.965 & 0.892 & 0.799 & 0.212 & 0.308 \\ 0.125 & 0.494 & 0.768 & 0.800 & 0.289 & 0.042 & 0.048 \\ 0.691 & 0.881 & 0.836 & 0.976 & 0.589 & 0.948 & 0.402 \\ 0.694 & 0.420 & 0.801 & 0.906 & 0.418 & 0.410 & 0.316 \\ 0.431 & 0.511 & 0.964 & 0.930 & 0.786 & 0.374 & 0.867 \\ 0.066 & 0.873 & 0.470 & 0.966 & 0.775 & 0.053 & 0.003 \\ 0.439 & 0.409 & 0.228 & 0.786 & 0.916 & 0.460 & 0.114 \\ 0.228 & 0.662 & 0.960 & 0.615 & 0.937 & 0.987 & 0.562 \\ 0.010 & 0.661 & 0.815 & 0.747 & 0.365 & 0.051 & 0.022 \\ 0.661 & 0.696 & 0.247 & 0.816 & 0.979 & 0.450 & 0.034 \\ 0.143 & 0.999 & 0.777 & 0.856 & 0.408 & 0.053 & 0.078 \\ 0.060 & 0.697 & 0.152 & 0.959 & 0.422 & 0.009 & <0.001 \\ 0.910 & 0.050 & 0.696 & 0.146 & 0.347 & 0.063 & 0.510 \\ 0.985 & 0.988 & 0.477 & 0.231 & 0.200 & 0.029 & 0.458 \\ 0.635 & 0.820 & 0.878 & 0.777 & 0.564 & 0.858 & 0.386 \\ 0.660 & 0.830 & 0.787 & 0.361 & 0.428 & 0.740 & 0.707 \\ 0.398 & 0.744 & 0.519 & 0.844 & 0.374 & 0.641 & 0.789 \\ 0.649 & 0.628 & 0.559 & 0.726 & 0.715 & 0.719 & 0.460 \\ 0.683 & 0.832 & 0.362 & 0.471 & 0.923 & 0.426 & 0.914 \\ 0.635 & 0.267 & 0.952 & 0.878 & 0.213 & 0.410 & 0.316 \\ 0.988 & 0.196 & 0.394 & 0.570 & 0.249 & 0.977 & 0.267\end{array}$

Experiment 2

Selection treatment

PS-PS-PS vs FS-FS-FS

PS-PS-PS vs PS-FS-PS

PS-PS-PS vs FS-PS-FS

PS-FS-PS vs FS-FS-FS

PS-FS-PS vs FS-PS-FS

FS-PS-FS vs FS-FS-FS

Season

Linear change season

Seed lot

Selection treatment $\times$ season

PS-PS-PS vs FS-FS-FS $\times$ linear season PS-PS-PS vs PS-FS-PS $\times$ linear season PS-PS-PS vs FS-PS-FS $\times$ linear season PS-FS-PS vs FS-FS-FS $\times$ linear season PS-FS-PS vs FS-PS-FS $\times$ linear season

$\begin{array}{lllllll}0.018 & 0.001 & 0.007 & 0.507 & 0.204 & 0.057 & 0.580 \\ 0.024 & <0.001 & 0.001 & 0.295 & 0.091 & 0.135 & 0.205 \\ 0.662 & 0.125 & 0.527 & 0.432 & 0.642 & 0.617 & 0.879 \\ 0.009 & 0.049 & 0.430 & 0.144 & 0.756 & 0.220 & 0.631 \\ 0.063 & 0.009 & 0.008 & 0.789 & 0.214 & 0.050 & 0.263 \\ 0.025 & 0.644 & 0.875 & 0.488 & 0.446 & 0.462 & 0.743 \\ 0.679 & 0.027 & 0.012 & 0.669 & 0.049 & 0.009 & 0.425 \\ 0.980 & 0.653 & 0.248 & 0.559 & 0.205 & 0.297 & 0.067 \\ 0.955 & 0.461 & 0.116 & 0.594 & 0.094 & 0.175 & 0.025 \\ <0.001 & 0.002 & 0.009 & 0.490 & 0.555 & <0.001 & <0.001 \\ 0.042 & <0.001 & 0.060 & 0.256 & 0.869 & 0.230 & 0.282 \\ 0.073 & 0.040 & 0.029 & 0.552 & 0.338 & 0.145 & 0.155 \\ 0.018 & 0.471 & 0.413 & 0.462 & 0.714 & 0.023 & 0.127 \\ 0.922 & 0.021 & 0.756 & 0.588 & 1.000 & 0.067 & 0.853 \\ 0.523 & 0.170 & 0.156 & 0.188 & 0.188 & 0.384 & 0.913 \\ 0.022 & 0.003 & 0.610 & 0.845 & 0.714 & 0.632 & 0.089\end{array}$


Table 3 (continued)

\begin{tabular}{|c|c|c|c|c|c|c|c|}
\hline \multirow[t]{2}{*}{ Factors and contrasts } & \multirow[t]{2}{*}{ Clean } & \multicolumn{6}{|l|}{ Virus } \\
\hline & & PLRV & PVX & PVY & PVA & PVS & PVM \\
\hline FS-PS-FS vs FS-FS-FS $\times$ linear season & 0.089 & $<0.001$ & 0.057 & 0.259 & 0.338 & 0.693 & 0.110 \\
\hline Selection treatment $\times$ seed lot & 0.212 & 0.980 & 0.973 & 0.891 & 0.971 & 0.509 & 0.014 \\
\hline PS-PS-PS vs FS-FS-FS $\times$ seed lot & 0.145 & 0.940 & 0.858 & 0.608 & 0.738 & 0.394 & 0.205 \\
\hline PS-PS-PS vs PS-FS-PS $\times$ seed lot & 0.662 & 0.805 & 0.896 & 0.548 & 0.642 & 0.617 & 0.615 \\
\hline PS-PS-PS vs FS-PS-FS $\times$ seed lot & 0.065 & 0.790 & 0.784 & 0.468 & 0.765 & 0.508 & 0.037 \\
\hline PS-FS-PS vs FS-FS-FS $\times$ seed lot & 0.302 & 0.748 & 0.757 & 0.929 & 0.895 & 0.180 & 0.080 \\
\hline PS-FS-PS vs FS-PS-FS $\times$ seed lot & 0.152 & 0.985 & 0.885 & 0.900 & 0.867 & 0.248 & 0.107 \\
\hline FS-PS-FS vs FS-FS-FS $\times$ seed lot & 0.679 & 0.733 & 0.650 & 0.830 & 0.972 & 0.848 & 0.001 \\
\hline Season $\times$ seed lot & 0.401 & 0.556 & 0.948 & 0.342 & 0.192 & 0.635 & 0.157 \\
\hline Linear season $\times$ seed lot & 0.228 & 0.591 & 0.900 & 0.162 & 0.118 & 0.453 & 0.742 \\
\hline Selection treatment $\times$ season $\times$ seed lot & 0.977 & 0.979 & 0.684 & 0.772 & 0.821 & 0.385 & 0.708 \\
\hline PS-PS-PS vs FS-FS-FS $\times$ linear season $\times$ seed lot & 0.441 & 0.735 & 0.390 & 0.190 & 0.680 & 0.505 & 0.155 \\
\hline PS-PS-PS vs PS-FS-PS $\times$ linear season $\times$ seed lot & 0.722 & 0.880 & 0.141 & 0.668 & 0.276 & 0.464 & 0.127 \\
\hline PS-PS-PS vs FS-PS-FS $\times$ linear season $\times$ seed lot & 0.922 & 0.801 & 0.545 & 0.533 & 1.000 & 0.210 & 0.537 \\
\hline PS-FS-PS vs FS-FS-FS $\times$ linear season $\times$ seed lot & 0.676 & 0.851 & 0.530 & 0.373 & 0.137 & 0.948 & 0.913 \\
\hline PS-FS-PS vs FS-PS-FS $\times$ linear season $\times$ seed lot & 0.649 & 0.267 & 0.952 & 0.878 & 0.213 & 0.410 & 0.316 \\
\hline FS-PS-FS vs FS-FS-FS $\times$ linear season $\times$ seed lot & 0.500 & 0.555 & 0.798 & 0.484 & 0.680 & 0.059 & 0.411 \\
\hline
\end{tabular}

Experiment 3

Selection treatment

PS-PS-PS vs FS-FS-FS

PS-PS-PS vs PS-FS-PS

PS-PS-PS vs FS-PS-FS

PS-FS-PS vs FS-FS-FS

PS-FS-PS vs FS-PS-FS

FS-PS-FS vs FS-FS-FS

Season

Linear change season

Seed lot

Selection treatment $\times$ season

PS-PS-PS vs FS-FS-FS $\times$ linear season

PS-PS-PS vs PS-FS-PS $\times$ linear season

PS-PS-PS vs FS-PS-FS $\times$ linear season

PS-FS-PS vs FS-FS-FS $\times$ linear season

PS-FS-PS vs FS-PS-FS $\times$ linear season

FS-PS-FS vs FS-FS-FS $\times$ linear season

Selection treatment $\times$ seed lot

PS-PS-PS vs FS-FS-FS $\times$ seed lot

PS-PS-PS vs PS-FS-PS $\times$ seed lot

PS-PS-PS vs FS-PS-FS $\times$ seed lot

PS-FS-PS vs FS-FS-FS $\times$ seed lot

PS-FS-PS vs FS-PS-FS $\times$ seed lot

FS-PS-FS vs FS-FS-FS $\times$ seed lot

Season $\times$ seed lot

Linear season $\times$ seed lot

Selection treatment $\times$ season $\times$ seed lot

PS-PS-PS vs FS-FS-FS $\times$ linear season $\times$ seed lot 0.763

PS-PS-PS vs PS-FS-PS $\times$ linear season $\times$ seed lot 0.377

PS-PS-PS vs FS-PS-FS $\times$ linear season $\times$ seed lot 0.383

PS-FS-PS vs FS-FS-FS $\times$ linear season $\times$ seed lot 0.497

PS-FS-PS vs FS-PS-FS $\times$ linear season $\times$ seed lot 0.678

FS-PS-FS vs FS-FS-FS $\times$ linear season $\times$ seed lot $\quad 0.274$
$<0.001 \quad 0.001$

$<0.001$

$0.277 \quad 0.036$

$<0.001<0.001$

$0.008 \quad 0.206$

$0.004 \quad 0.093$

$0.431 \quad 0.669$

$0.008 \quad 0.173$

$0.003 \quad 0.073$

$<0.001 \quad 0.160$

$0.005 \quad 0.427$

$0.616 \quad 0.960$

$\begin{array}{ll}0.052 & 0.817\end{array}$

$0.104 \quad 0.776$

$0.143 \quad 0.856$

$0.738 \quad 0.958$

$0.255 \quad 0.814$

$<0.001 \quad 0.990$

$<0.001 \quad 0.858$

\begin{tabular}{ll}
$0.308 \quad 0.832$ \\
\hline
\end{tabular}

$<0.001 \quad 0.973$

$0.013 \quad 0.942$

$<0.001 \quad 0.770$

$0.125 \quad 0.860$

$<0.001 \quad 0.615$

$<0.001 \quad 0.549$

0.972

0.978

0.996

0.735

0.972

0.759

0.820 $\begin{array}{llll}0.108 & 0.097 & 0.043 & 0.004\end{array}$

$\begin{array}{llll}0.017 & 0.075 & 0.119 & 0.014\end{array}$

$\begin{array}{llll}0.183 & 0.191 & 0.006 & 0.827\end{array}$

$\begin{array}{llll}0.102 & 0.016 & 0.040 & 0.008\end{array}$

$\begin{array}{llll}0.266 & 0.623 & 0.216 & 0.008\end{array}$

$\begin{array}{llll}0.753 & 0.250 & 0.470 & 0.005\end{array}$

$\begin{array}{llll}0.422 & 0.507 & 0.602 & 0.843\end{array}$

$\begin{array}{lllll}0.119 & 0.002 & 0.007 & 0.033\end{array}$

$\begin{array}{lllll}0.119 & 0.002 & 0.007 & 0.033 & <0.001 \\ 0.165 & 0.026 & 0.105 & 0.016 & 0.001\end{array}$

$\begin{array}{llllll}0.511 & 0.015 & 0.098<0.001<0.001\end{array}$

$\begin{array}{lllll}0.799 & 0.759 & 0.212 & 0.255 & 0.914\end{array}$

$\begin{array}{lllll}0.728 & 0.332 & 0.220 & 0.954 & 0.694\end{array}$

$\begin{array}{lllll}0.611 & 0.648 & 0.321 & 0.153 & 0.921\end{array}$

$\begin{array}{llllll}0.623 & 0.362 & 0.295 & 0.148 & 0.601\end{array}$

$\begin{array}{lllll}0.872 & 0.606 & 0.812 & 0.138 & 0.769\end{array}$

$\begin{array}{lllll}0.319 & 0.648 & 0.955 & 0.986 & 0.672\end{array}$

$\begin{array}{lllll}0.402 & 0.953 & 0.856 & 0.133 & 0.869\end{array}$

$\begin{array}{llllll}0.803 & 0.552 & 0.350 & <0.001 & 0.636\end{array}$

$\begin{array}{llllll}0.767 & 0.694 & 0.622 & 0.018 & 0.600\end{array}$

$\begin{array}{lllll}0.348 & 0.164 & 0.164 & 0.953 & 0.710\end{array}$

$\begin{array}{llllll}0.410 & 0.369 & 0.476 & 0.001 & 0.279\end{array}$

$\begin{array}{llllll}0.640 & 0.378 & 0.308 & 0.008 & 0.976\end{array}$

$\begin{array}{llllll}0.985 & 0.577 & 0.104 & <0.001 & 0.391\end{array}$

$\begin{array}{lllll}0.735 & 0.839 & 0.818 & 0.600 & 0.320\end{array}$

$\begin{array}{llllll}0.057 & 0.763 & 0.122 & 0.003 & 0.628\end{array}$

$\begin{array}{llllll}0.147 & 0.508 & 0.707 & 0.001 & 0.315\end{array}$

$\begin{array}{llllll}0.527 & 0.841 & 0.272 & 0.553 & 0.957\end{array}$

$\begin{array}{llllll}0.491 & 0.691 & 0.766 & 0.606 & 0.620\end{array}$

$\begin{array}{lllll}0.228 & 0.369 & 0.913 & 0.592 & 0.712\end{array}$

$\begin{array}{lllll}0.330 & 0.305 & 0.499 & 0.409 & 0.469\end{array}$

$\begin{array}{lllll}0.785 & 0.282 & 0.945 & 0.382 & 0.788\end{array}$

$\begin{array}{lllll}0.581 & 0.802 & 0.437 & 0.636 & 0.852\end{array}$

$\begin{array}{lllll}0.458 & 0.403 & 0.289 & 0.108 & 0.887\end{array}$

Entries in italics indicate a significant $P$ value 


\section{Results}

Figures 4 and 5 show in detail the effects of the selection treatments on incidence of viruses in successive seasons, in the different seed lots and experiments. Table 3 shows the accompanying ANOVA analysis with significances of the effects of the factors (a) selection treatment, (b) season, and (c) seed lot and their interactions. For the factor selection treatment, the contrasts between the individual selection treatments were also tested, because in part of the selection treatments, the applied selection method varied over the seasons, thereby increasing the variation of the main effect. For the factor season, the significance of a linear component was tested indicating if there was a significant increase or decrease in virus incidence across multiple seasons of selection. No significant three-way interactions were found in any of the experiments. Table 4 shows the effects of the selection treatments across seasons and seed lots in the three experiments. Results of virus incidences are first described for the proportion of clean plants (tested negative for all viruses tested) and, thereafter, for viruses giving severe visible symptoms (PLRV and PVX), followed by mild visual symptoms (PVY and PVA) and weak visual symptoms (PVS and PVM).

\section{Effects of Selection Treatments on Virus Incidence}

Continuous positive selection (PS-PS-PS) in general decreased the virus incidence compared to continuous farmers' selection (FS-FS-FS) (Table 4; Fig. 5). The treatment with PS in two of the three seasons (PS-FS-PS) usually outperformed (when different) the treatment with PS in only one of the three seasons (FS-PS-FS); however, differences between them were hard to detect as statistically significant (Table 3).

The percentage of clean plants was higher in the PS-PS-PS treatment than in the FSFS-FS treatment for cv. Katchpot 1 and cv. Rwangume (Fig. 4), with the differences being significant in Experiments 2 and 3 (Table 4). The relative increase of clean plants by PS-PS-PS treatment compared to FS-FS-FS treatment was $47 \%$ in Experiment 3 and $37 \%$ in Experiment 2 (Table 4). In the farm-saved seed lot of cv. Rwangume, an increase in time in the proportion of clean tubers took place. In the PS-PS-PS treatment, $93 \%$ of the tubers was clean after three seasons of selection and in the FS-FS-FS treatment $67 \%$. In cv. Victoria, almost no clean plants were found in all three experiments.

The decrease in virus incidence by continuous positive selection (PS-PS-PS) compared to continuous farmers selection (FS-FS-FS) was statistically significant for PLRV and PVX in all experiments (Table 3); relative decreases up to 35 and 34\%, respectively, were achieved (Table 4). For PLRV in Experiment 2, a significant two-way interaction between selection treatment and season (Table 3) showed that the difference in virus incidence between FS-FS-FS and PS-PS-PS increased with season.

PVY and PVA were generally present at low levels (Fig. 5, Table 4), and the decrease in virus incidence by applying positive selection compared to farmers' selection was not significant.

The decrease by applying positive selection was also not significant for the incidence of PVS in Experiments 1 and 2 with highly infected seed lots of cv. Victoria and PVM in both cultivars in Experiments 1, 2, and 3 (Fig. 5, Tables 3 and 4). For PVS in Experiment 3, significant selection treatment $\times$ seed lot interaction (Table 3 ) showed that in the farm-saved seed lot of cv. Rwangume with intermediate infection levels of 


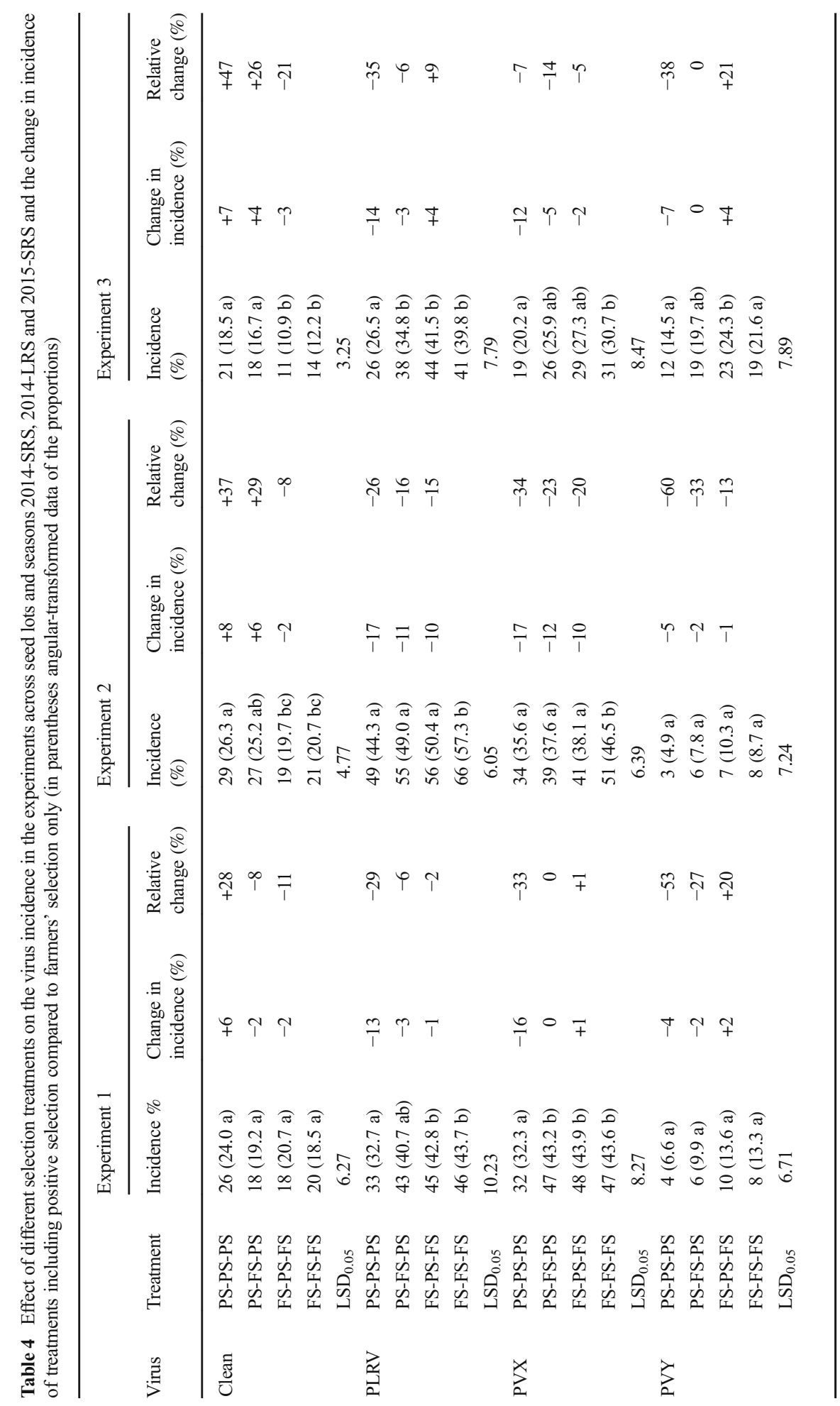




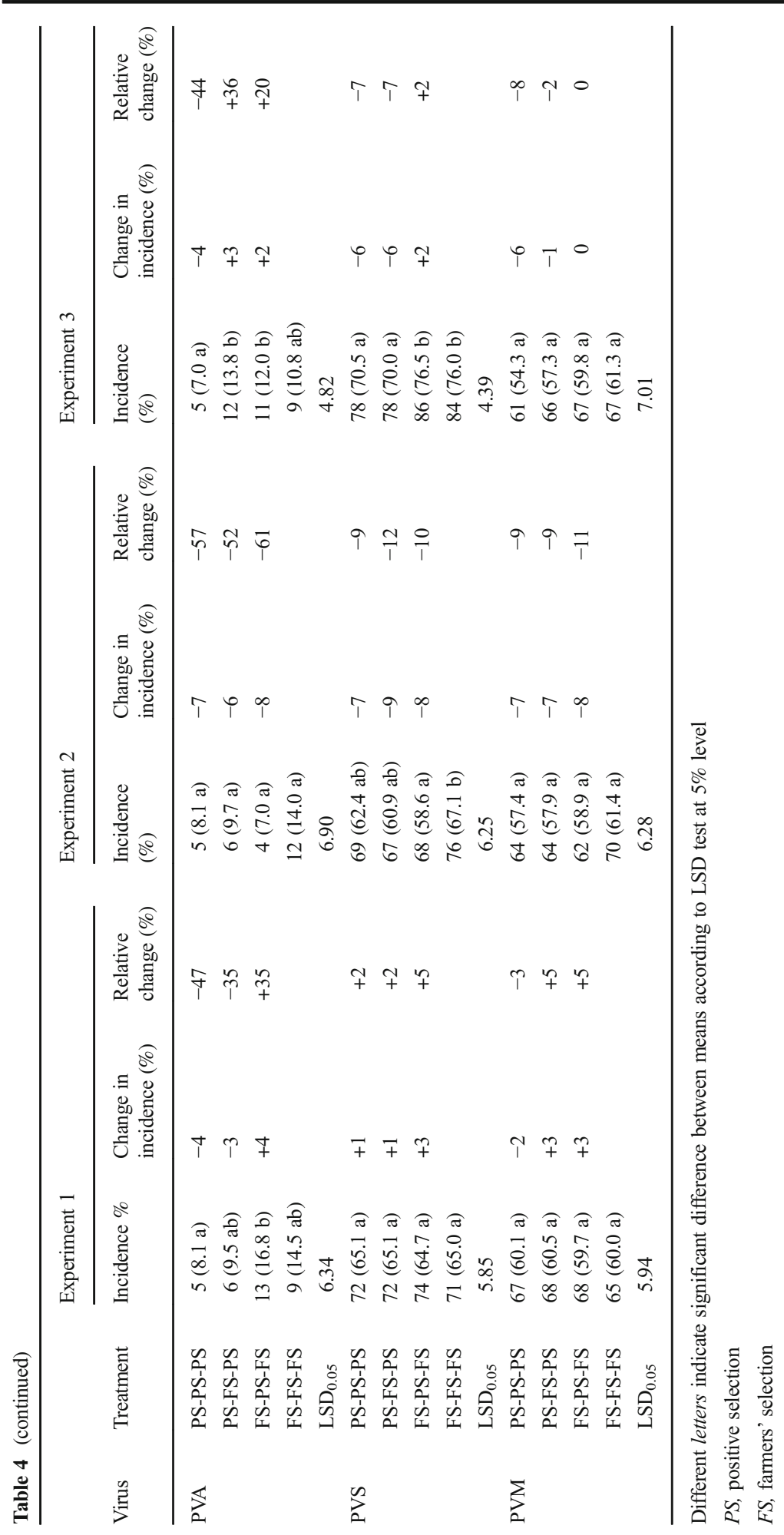




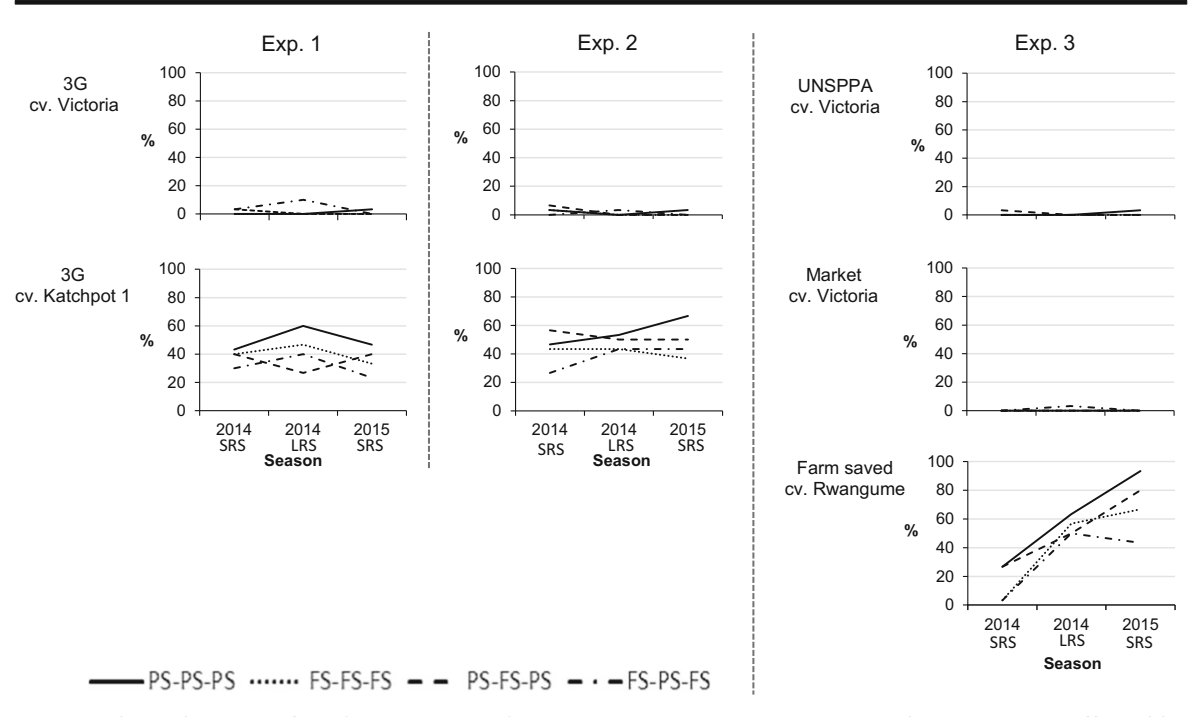

Fig. 4 Clean plants (\%) found at emergence in seasons 2014-SRS, 2014-LRS, and 2015-SRS as affected by different seed selection treatments in the previous seasons in different seed lots in the three experiments

PVS, PS-PS-PS resulted in lower incidence of PVS than FS-FS-FS, whereas in the highly infected seed lots of cv. Victoria, there was no decrease in PVS incidence by positive selection (Fig. 5).

\section{Differences in Virus Incidence Between Seed Lots}

In all experiments, there was a significant effect of the seed lot on the percentage clean plants (Table 3). All seed lots of cv. Victoria (5G, 4G, or market seed) showed almost no clean plants (Fig. 4). The level was significantly lower than that of the $3 \mathrm{G}$ seed lots of cv. Katchpot 1 in Experiments 1 and 2 and that of the 5G farm-saved seed lot of cv. Rwangume in the later seasons in Experiment 3 (Fig. 5).

PLRV and PVX were present at intermediate levels in all seed lots in all experiments. There were no effects of the seed lot on PLRV incidence in Experiments 1 and 3 (Table 3), whereas in Experiment 2, the 3G seed lot of cv. Victoria had a higher PLRV incidence than the $3 \mathrm{G}$ seed lot of cv. Katchpot 1 (Fig. 5). PVX incidence was significantly higher in the $3 \mathrm{G}$ seed lot of cv. Victoria than in that of cv. Katchpot 1 in Experiments 1 and 2; it was not affected by the seed lot in Experiment 3 (Table 3). No significant interactions between seed lot and other experimental factors were found for incidence of these viruses.

In general, a low incidence of PVY and PVA was found in Experiments 1 and 2 (Fig. 5) and there were no significant effects of seed lot on the incidence of PVY and PVA in these experiments (Table 3). In Experiment 3, effects of seed lot were significant for PVY (Table 3), with higher incidences in the $4 \mathrm{G}$ and market seed lots of cv. Victoria than in the 5G farm-saved seed of cv. Rwangume (Fig. 5); no significant effects of seed lot on PVA incidence were found in Experiment 3 (Table 3). Regarding PVY and PVA incidence, there were no significant interactions between the experimental factors in the experiments. 


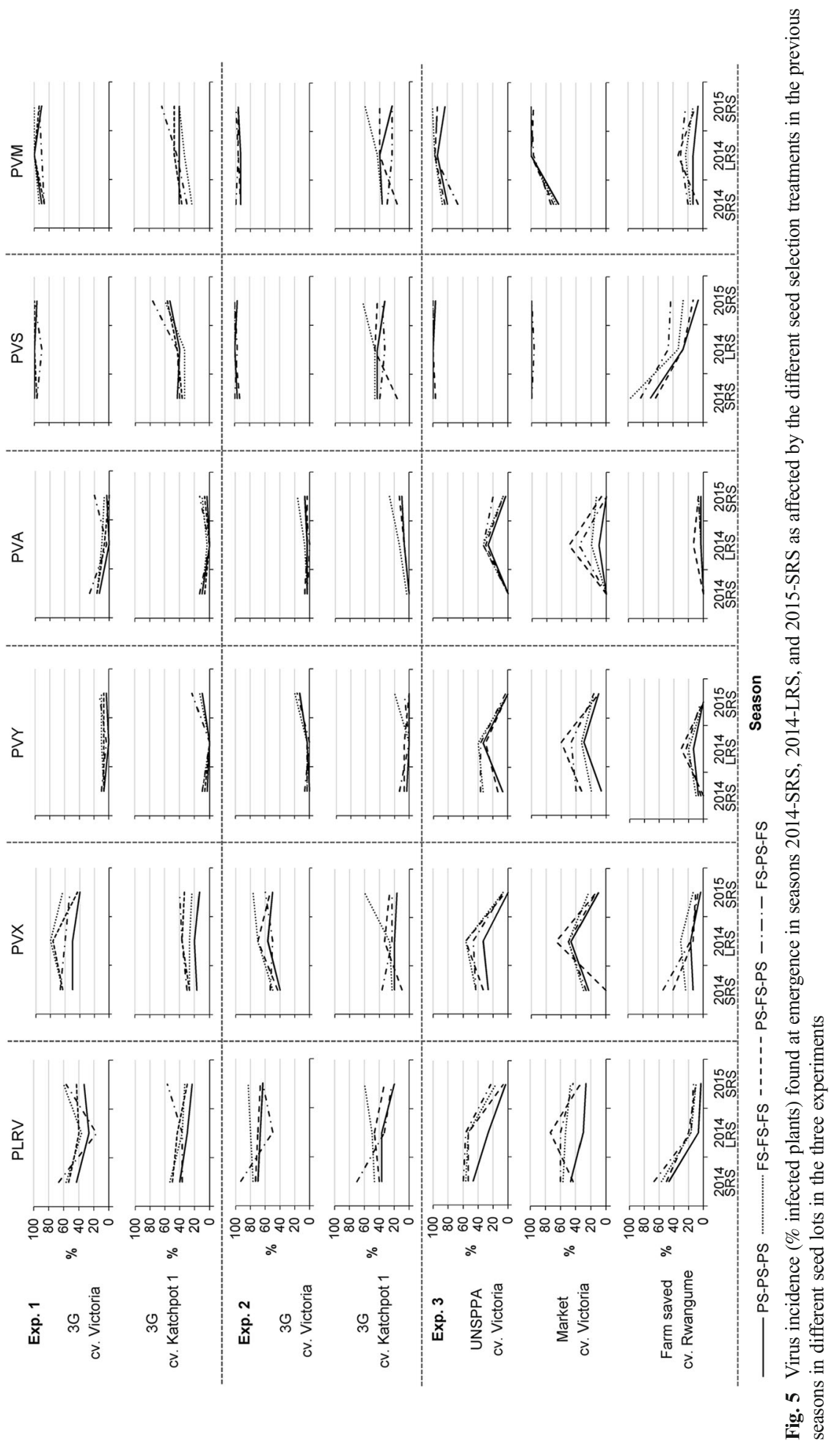


In seed lots from cv. Victoria, PVS and PVM incidences were very high in all seasons at almost $100 \%$ in all experiments, whereas seed lots from cv. Katchpot 1 (in Experiments 1 and 2) and cv. Rwangume (in Experiment 3) had significantly lower incidences of PVS and PVM (Fig. 5). Significant linear season $\times$ seed lot interaction showed that in Experiment 1, the difference between seed lots in PVS incidence tended to become smaller with season. Significant seed lot $\times$ selection treatment and seed lot $\times$ season interactions in Experiment 3 showed that the difference between seed lots in PVS incidence was larger under PS-PS-PS than under FS-FS-FS treatment, and that differences in incidence between seed lots increased with season (Table 3, Fig. 5). In Experiments 1 and 2, a significant seed lot $\times$ selection treatment interaction was found for PVM incidence.

\section{Changes in Virus Incidence Over Time}

Because different selection methods were thought to exert their effects season after season, with the difference between them becoming gradually larger with time, it was expected that there would be significant interactions between season and selection treatment, especially between season and the contrast between continuously positive selection and continuously farmers' selection.

There were no significant changes across the seasons in percentage of clean plants in Experiments 1 and 2, nor any significant interactions between seed lot and season or the contrast between PS-PS-PS and FS-FS-FS and season (Table 3); this shows that the percentage of clean plants did not change differently in time between the seed lots or between the most extreme selection treatments. Only incidental interaction between season and the contrast between continuous positive selection and the treatment in which positive selection was interrupted by one season of farmers' selection was found in Experiment 2.

The virus incidence often fluctuated strongly over seasons for viruses present at intermediate levels, like PLRV and PVX in all seed lots and PVY and PVA in the seed lots of Experiment 3 (Fig. 5). There was limited fluctuation in time for viruses present at almost $100 \%$ incidence, like PVS and PVM in seed lots of cv. Victoria, or present at very low levels, like PVY and PVA in Experiments 1 and 2 (Fig. 5).

For PLRV and PVX, present at intermediate levels in all experiments, the virus incidence usually fluctuated strongly over seasons (Fig. 5), whereas main effects of season were not significant. In Experiment 2, significant interactions between season and selection treatment (for PLRV) and between season and the contrast between continuously FS and continuous PS (for PVX) showed that the difference between FS-FS-FS and PS-PS-PS in incidence of these viruses significantly increased with time (Table 3); the lowest PLRV incidence was found when PS-PS-PS was applied. In Experiment 3, PLRV and PVX incidence tended to decrease significantly with time in cv. Victoria/UNSPPA and cv. Rwangume (Fig. 5).

In Experiments 1 and 2, no or a low incidence of PVY and PVA was found. A weak linear increase across the seasons was present for PVA in Experiment 1, but no further season-related effects were observed for PVY or PVA in these experiments (Fig. 5, Table 3). In Experiment 3, the incidence in PVY and PVA fluctuated across seasons. None of the changes in PVY and PVA incidence across seasons was related to the 
selection treatments affecting these changes, as shown by the lack of selection treatment $\times$ season interactions (Table 3 ).

In seed lots from cv. Victoria, PVS and PVM were present in all seasons at almost $100 \%$ incidence in all experiments, whereas the seed lots from cv. Katchpot 1 in Experiments 1 and 2 and from cv. Rwangume in Experiment 3 had lower incidences of PVS and PVM (Fig. 5). In Experiment 1, the difference in PVS incidence between seed lots tended to decrease linearly with time as shown by a significant interaction between the linear component of season and seed lot (Table 3); this was found because, while cv. Victoria remained almost fully infected in time, the infection levels in cv. Katchpot 1 increased in time. No significant effects of season or interactions between seed lot and season were found in Experiment 2. In Experiment 3, again the interaction between seed lot and the linear component of season was significant. Also, in Experiment 3, the two seed lots from cv. Victoria remained fully infected in time, but in contrast to Experiment 1, the PVS incidence in the third seed lot, now the 5G farmsaved seed lot of cv. Rwangume in which a very high incidence was present in the 2 nd season (SRS-2014), declined efficiently in the subsequent seasons (Fig. 5, Table 3). In none of the experiments was the seed lot-specific decrease or increase in PVS incidence in time driven by the selection treatments, because there were no significant three-way interactions. For PVM incidence, there were no effects of season in Experiment 1, whereas small linear changes in time were found in Experiments 2 and 3. In Experiment 2, there was a decrease over time in cv. Katchpot 1. In Experiment 3, across the seasons, there was a significant increase in PVM incidence. No interactions with season were significant for PVM incidence.

\section{Aphid Monitoring}

Aphid catches varied among the three locations and among seasons (Fig. 2). The highest records of aphids were found in Karengyere, the location of Experiment 1, in the short rainy seasons 2014-SRS, with a total number of 2121, and 2015-SRS, with a total number of 3096. In the long rainy season 2014-LRS, a total number of 385 were counted. In Kachwekano, the location of Experiment 2, the total number was 557 in the 2nd season, 2014-SRS, and 303 in the 4th season, 2015-SRS, while in the 3rd season, 2014-LRS, a total number of 226 were recorded. The 3rd season 2014-LRS was characterised by rainfall throughout the growing period; in the 1st season 2013-LRS and 3rd season 2014-LRS, rainfall spread more throughout the season than in 2014SRS and 2015-SRS (Fig. 3). In Experiment 3, the lowest total number of the aphid catches was found with 265 in the 2nd season 2014-SRS and 140 in the 4th season 2015-SRS; in the 3rd season 2014-SRS, 84 aphids were caught. At all three sites, aphid flights were prevalent before and during the recommended period for positive selection.

\section{Virus Incidence in Crops from the Starting Seed Lots}

Due to technical inability in setting up a local virus testing facility, the virus incidence in the starting seed lots in the first season could not be assessed immediately after emergence as in later seasons, but only at the moment of positive selection, i.e., just before full flowering. In the crops grown from the $3 \mathrm{G}$ seed lots in the first season in Experiment 1 (Table 2), 5\% of the plants of cv. Victoria and $75 \%$ of the plants of $\mathrm{cv}$. 
Katchpot 1 were fully free of virus at that moment (Table 2). In cv. Victoria, considerable incidence of PLRV and PVX was found (20 and 23\% of the plants, respectively), a low level of PVY (5\%), no PVA and high levels of PVS and PVM (95 and 63\%, respectively). In the crop from cv. Katchpot 1, the incidences of PLRV and PVX were low (3 and 7\%, respectively), and for PVY and PVA incidental (each 2\%). In crops from the seed lot of this cultivar, a PVS incidence of $17 \%$ and a PVM incidence of $25 \%$ were found.

In Experiment 3, there were no fully virus-free plants in the crops from the $4 \mathrm{G}$ UNSPPA and local market seed lots of cv. Victoria, but notably, $47 \%$ virus-free plants in the crop from the $5 \mathrm{G}$ farm-saved seed of cv. Rwangume. All three crops showed minor infections with PLRV (2, 8, and 7\%, respectively) and (minor) infections with PVX (UNSPPA 5\%, local market 3\%, farm-saved seed 18\%). Incidence of PVY was absent in the seed lot from UNSPPA, and low in the market and farm-saved seed lots (2\%); PVA was found to a minor extent in all three seed lots $(5,7$, and $7 \%$, respectively). Also in this experiment, crops from the cv. Victoria seed lots (from UNSPPA and the local market) showed high infection with PVS (100\%) and PVM (65 and 78\%, respectively); in plants from the farm-saved seed lot of cv. Rwangume, these viruses were also present but at a much lower level (PVS 32\%, PVM 12\%).

\section{Efficiency of Plant Selection Regarding Virus Incidence in the First Season}

Comparing the virus incidences in the full plots from the original seed lots to the virus incidence in the PS plants selected in the first season (Table 2) revealed that PS reduced the incidence of PLRV and PVX in the plants to be used for seed production to low levels in cv. Victoria and to no infection in cv. Katchpot 1 in Experiment 1 (Table 2), but the effects were hardly significant $(P=0.051$, Table 2$)$. For PVY and PVA, where virus levels were already lower than those of PLRV and PVX, the reduction in virus incidence by selecting PS plants was not significant. There were also no significant differences between incidence levels in plants from the original seed lot and PS selected plants for the other viruses (PVS and PVM) in Experiment 1, nor for any of the viruses in Experiment 3 (Table 2).

We noticed there were large differences in the fraction of plants with PLRV and PVX between replicated plots in both experiments, with some plots being fully clean and others infected to a considerable extent. In Experiment 1, the blocks were laid out in a linear outline starting from Block I to Block III. In Block III and especially in the last plots, incidences of PLRV were highest, probably because these plots were closest to the border of the field with bushes. Also, PVX incidences were most abundant in the last plots. In Experiment 3, most incidences of PLRV and PVX were found in the outer plots of the blocks.

\section{Increase in Virus Incidence After Plant Selection}

The quality of the tubers produced after a season of selection was assessed in plants soon after emergence in the next season; the early time being necessary to avoid possible early primary infections interfering with the assessment. In the second season (2014-SRS), tuber data at emergence could be compared with the data of the plants they originated from at the moment when positive selection took place (2013-LRS). 
Regardless of the selection treatment, the virus incidence in the plants from these tubers was considerably higher than the incidence found in the plants they originated from at the moment before full flowering (i.e., the moment at which positive selection also took place), whereas the percentage of clean plants (when present) was lower (Table 2). This suggests that the infection levels increased in the period between selecting plants and planting in both selection treatments.

\section{Discussion}

\section{Reduction of Virus Incidence by Positive Selection as Compared to Farmers' Selection}

Our results clearly show that crops planted with seeds from positive selection have a reduced virus incidence compared to those from farmers' selection when the treatments are applied over multiple (in our case, three) seasons, thereby reducing the level of secondary infection in the next-season crop (Tables 3 and 4; Figs 4 and 5). Selection treatments in which positive selection was applied in one or two out of the three seasons took an intermediate position. However, this reduction of virus incidence by positive selection was not found for all virus species, and the reduction was less strong than expected based on Gildemacher et al. (2011) and Schulte-Geldermann et al. (2012).

Positive Selection for Different Virus Species The reduction in virus incidence by positive selection was clear for PLRV and PVX in all seed lots. These virus species display clear visual symptoms (Loebenstein et al. 2001) and were present at intermediate incidence (Fig. 5). Incidences of PVY and PVA (displaying mild visual symptoms) could be maintained at the levels as assessed after emergence in the 2nd season, despite the small (not significant) trend to increase at the end in Experiment 2 in Kachwekano. Symptoms for PVS and PVM are poorly visible in the crop (Loebenstein et al. 2001). The initial high percentage of incidence for PVS and PVM in cv. Victoria also explains why positive selection was not able to significantly increase the percentage of clean plants in seed lots from this cultivar (Tables 3 and 4). The levels of PVS and PVM in cv. Katchpot 1 could reasonably be maintained across years by positive selection, especially in Experiment 2. In cv. Rwangume in Experiment 3, a decrease in PVS incidence was found across seasons (Fig. 5), but this was not exclusively found under PS-PS-PS management. CV. Rwangume might be resistant to PVS and may be able to combat the virus itself. However, the incomplete autoinfection of tubers may be important (Bertschinger et al. 2017). Incomplete autoinfection will result in planting partly clean seed because not all daughter tubers of an infected plant will be infected. A regeneration (meaning more clean plants) of a degenerated crop might be enhanced by applying positive selection in cv. Rwangume, because of a higher percentage of cleaner plants. In all other seed lots, a regeneration by applying positive selection was possible for selected viruses present at intermediate incidence levels, like PLRV and PVX. The clear significant effect of the seed lots, which was attributed to the different cultivars tested in the experiments, is in line with the results of Schulte-Geldermann et al. (2012) that cultivars or genotypes differ in their response to the tested viruses. 
Reasons for Limited Gain by Positive Selection There are several possible reasons why positive selection did not reduce the virus level as strongly as we expected in advance.

An important factor for the limited gain by positive selection may be a high (risk for) primary infection in this region, because of (i) a high basic level of virus incidence in the environment, as shown by Fuglie (2007), with even the $3 \mathrm{G}$ seed lots having a high incidence of PVS and PVM (Fig. 5, Table 2) and (ii) a high risk of virus transmission. The high risk of virus transmission in our experiments can be shown by (1) the seasonal fluctuations in all selection treatments that indicate reinfection occurred (Fig. 5) and (2) the increase in virus incidence after the moment of selecting in the first season (Table 2). A high risk of virus transmission in the region might be caused by (a) the presence of aphids already before and after the moments of positive selection (Fig. 2), (b) field traffic including manual spraying, and (c) the relatively small plot size (Pourrahim et al. 2007). The average area of potato plots in Kabale and Kisoro districts was shown to be 0.23 ha (Kaguongo et al. 2008). In our experiments, the small experimental plots and the presence of farmers' selection plots will have aggravated this risk for primary infection. For mechanical spread of viruses, the movement of the sprayer through the field (to spray against Phytophthora infestans) or walking through the potato plots to select the plants might have enhanced virus spread, particularly for PVX. Different aphid pressure throughout the seasons (Fig. 2) and different locations including neighbouring crops (Table 1) may determine infection pressure through the presence and abundance of aphid-transmitted virus diseases (e.g., PLRV) (Fig. 2). Windy and open environments do not favour aphid pressure, which might be the reason for the low number of aphids in Experiment 3.

Another reason for achieving less reduction in virus incidence by positive selection than expected (Fig. 5) and a lower number of clean plants (Fig. 4) will have been the low selection pressure possible in the plots. Bacterial Wilt (Ralstonia solanacearum) was common in many fields limiting the number of plants available for positive selection. Moreover, a minimum number of seed tubers were needed to plant the field experiments for the next season; therefore, it was necessary to choose and select $37.5 \%$ of the plants in the net plot. At the yield levels in Uganda, this is a realistic proportion for a farmer's field in order to have enough medium-sized seed tubers for the same area of land in the next season, due to low multiplication rate of the plants. Besides, it turned out to be very difficult to find fully vigorous plants, which might be attributed to the growing conditions in this region, such as poor soil fertility and poor rainfall, which reduce plant vigour as well.

\section{Seed Tuber Quality of the Starting Seed Lots}

The seed tuber quality of the starting seed lots (as assessed in crops from these tubers at the moment of flowering) of the different sources and cultivars varied but was not always as expected. The quality declared $3 \mathrm{G}$ and $4 \mathrm{G}$ seed of the research station KAZARDI, and the private seed grower UNSPPA, respectively, was expected to be clean or contain little virus, but this was not the case. Of the $3 \mathrm{G}$ plants, 5-75\% was clean, whereas no clean plant was found in the crop from the 4G UNSPPA seed lot (Table 2). Incidence of PVS and PVM was already high in crops from these tubers, particularly for cv. Victoria. Cultivar Victoria may be 
more susceptible to PVS and PVM infection than cv. Katchpot 1, of which the original $3 \mathrm{G}$ seed had the lowest virus incidence of all seed lots, with $75 \%$ clean plants. The high incidence of these viruses suggests that PVS and PVM are not reliably selected against in the seed system sector. PVS and PVM also showed high incidence in the seed lot from the local market and to some extent in the farm-saved seed lot in Experiment 3.

Recycled seed potatoes from the informal sector like the market seed were expected to have the highest virus incidence, but surprisingly low levels of PLRV, PVX, PVY, and PVA were found. This also held for the farm-saved 5G seed of cv. Rwangume which was healthier than expected with $50 \%$ clean plants.

\section{Efficiency of Plant Selection}

In the first season, the virus incidence in the positive-selected plants was assessed at the moment of positive selection and compared to that in the unselected FS crops (Table 2). Although virus infection levels were generally lower or even zero in the positive selection plants, this turned out to be barely statistically significant $(P=0.051$ for PLRV and PVX in Experiment 1). This lack of significance was at least partly due to infections being localised, resulting in an uneven distribution of the virus in the blocks and plots, which greatly increased variation.

\section{Recommendations}

Positive selection is selecting plants based on visual symptoms, which is relevant for innovative seed system management practices in low-income countries. The research showed that positive selection can be a long-term strategy to keep incidence of viruses with clear visual symptoms in plants at lower levels than in farmers' selection. However, it is hard to flush out viruses where no obvious symptoms occur or when seed lots are fully infected; therefore, positive selection also has limitations. Another overall solution to combat degeneration is to use virus-free and virus-resistant planting material from institutes and private seed growers, which currently might be difficult to purchase in Uganda. Therefore, institutes and private seed growers should invest in more reliable virus testing and seed production management. However, due to financial constraints of smallholder farmers, this cannot be seen as a silver bullet for Uganda (Thomas-Sharma et al. 2016). Another recommendation for farmers might be seed plot technology (Kakuhenzire et al. 2005; Kinyua et al. 2015) where a separate plot of tubers is grown for production of seed tubers. Within this plot, positive selection is applied and tubers from the selected plants are used to establish the next-season seed plot, whereas the remaining tubers are used to grow the ware crop. Positive selection as an innovative seed degeneration management method for resource poor farmers is currently the best-to-fit and a resilient method; this suggests farmers have to be trained in good seed management practices to achieve the best possible potato yields.

Acknowledgements This work has been conducted as part of a Ph.D. thesis project supported by the Agricultural Transformation by Innovation (AGTRAIN) Erasmus Mundus Joint Doctorate Program, funded by the EACEA (Education, Audiovisual and Culture Executive Agency) of the European Commission. The authors thank Gerald Baguma and the family of John and Fedelis Karugaba. 
Compliance with Ethical Standards There were no human or animal experimentation involved.

Conflicts of Interest The authors declare that they have no conflict of interest.

Open Access This article is distributed under the terms of the Creative Commons Attribution 4.0 International License (http://creativecommons.org/licenses/by/4.0/), which permits unrestricted use, distribution, and reproduction in any medium, provided you give appropriate credit to the original author(s) and the source, provide a link to the Creative Commons license, and indicate if changes were made.

\section{References}

Awhere (2016) http://www.awhere.com. Accessed 8 September 2016

Bertschinger L, Bühler L, Dupuis B, Duffy B, Gessler C, Forbes GA, Keller ER, Scheidegger UC, Struik PC (2017) Incomplete infection of secondarily infected potato plants - an environment dependent underestimated mechanism in plant virology. Front Plant Sci 8:1-13. https://doi.org/10.3389 /fpls.2017.00074

de Bokx JA, van der Want JPH (1987) Viruses of potatoes and seed-potato production, 2nd edn. Centre for Agricultural Publishing and Documentation, Wageningen

Döring TF (2011) Potential and limitations of plant virus epidemiology: lessons from the potato virus Y pathosystem. Potato Res 54:341-354. https://doi.org/10.1007/s11540-011-9195-0

Fernandez GCJ (1992) Residual analysis and data transformations: important tools in statistical analysis. Hort Science 27:297-300

Fuglie KO (2007) Priorities for potato research in developing countries: results of a survey. Am Potato J 84: 353-365

Gildemacher P, Demo P, Kinyae P, Wakahiu M, Nyongesa M, Zschocke T (2007) Select the best: positive selection to improve farm saved seed potatoes. Trainers Manual. International Potato Center, Lima

Gildemacher PR, Demo P, Barker I, Kaguongo W, Woldegiorgis G, Wagoire WW, Wakahiu M, Leeuwis C, Struik PC (2009) A description of seed potato systems in Kenya, Uganda and Ethiopia. Am Potato J 86: 373-382. https://doi.org/10.1007/s12230-009-9092-0

Gildemacher PR, Schulte-Geldermann E, Borus D, Demo P, Kinyae P, Mundia P, Struik PC (2011) Seed potato quality improvement through positive selection by smallholder farmers in Kenya. Potato Res 54: 253-266. https://doi.org/10.1007/s11540-011-9190-5

Guzmán-Barney M, Franco-Lara L, Rodríguez D, Vargas L, Fierro JE (2012) Yield losses in Solanum tuberosum group Phureja cultivar Criolla Colombia in plants with symptoms of PYVV in field trials. Am Potato J 89:438-447. https://doi.org/10.1007/s12230-012-9265-0

International Potato Center (CIP) (2011) Roadmap for investment in the seed potato value chain in Eastern Africa. CIP, Nairobi

Jeffries C (1998) Technical guidelines for the safe movement of germplasm. No. 19. Potato. FAO and IPGRI, Rome

Kaguongo W, Gildemacher P, Demo P, Wagoire W, Kinyae P, Andrade J, Forbes G, Fuglie K, Thiele G (2008) Farmer practices and adoption of improved potato varieties in Kenya and Uganda. Social Sciences Working Paper 2008-5. International Potato Center (CIP), Lima

Kakuhenzire R, Musoke C, Olanya M, Kashzija I, Smith J, Wagoire W, Kinyua Z, Namanda S (2005) Validation, adaptation and uptake of potato small seed plot technology among rural, resource-limited households in Uganda. Afr Crop Sci Conference Proceedings 7:1355-1361

Kinyua ZM, Bararyenya A, Schulte-Geldermann E, Obura BO, Kashaija IN, Tindimubona S, Opio F, Oyena D, Rwomushana WM, Muriithi WM, Kinoti J, Namugga P, Kimoone G, Inamahoro M, Niko N, Ndayihanzamaso P (2012) Overcoming seed potato quality constraints to tackle food insecurity and poverty in eastern and central Africa in the 21st century. Association for Strengthening Agricultural Research in Eastern and Central Africa. Accessed from http://www. asareca.org/sites/default/files/SeedpotatoqualityASARECAGA.pdf Accessed 10 July 2016

Kinyua ZM, Schulte-Geldermann E, Namugga P, Ochieng-Obura B, Tindimubona S, Bararyenya A, Kashaija IN, Rwomushana I, Opio F (2015) Adaption and improvement of the seed-plot technique in smallholder potato production. In: Low J, Nyongesa M, Quinn S, Parcer M (eds) Potato and sweetpotato in Africa: transforming the value chains for food and nutriton security. CAB International, Nairobi, pp 218-225 
Loebenstein G, Berger PH, Brunt AA, Lawson RH (2001) Virus and virus-like diseases of potatoes and production of seed-potatoes. Kluwer Academic Publishers, Dordrecht

Loebenstein G, Gaba V (2012) Viruses of potato. In: Loebenstein G, Lecoq H (eds) Advances in virus research, vol 84. Elsevier Inc., Bet Dagan, pp 209-246. https://doi.org/10.1016/B978-0-12-3943149.00006-3

Pourrahim R, Farzadfar S, Golnaraghi AR, Ahoonmanesh A (2007) Incidence and distribution of important viral pathogens in some Iranian potato fields. Plant Dis 91:609-615. https://doi.org/10.1094/PDIS-91-50609

Primediagnostics (2013) http://www.primediagnostics.com. Accessed 20 Dec 2013

Salazar LF (1996) Potato viruses and their control. International Potato Center, Lima. ISBN 92-9060-184-1

Schulte-Geldermann E, Gildemacher PR, Struik PC (2012) Improving seed health and seed performance by positive selection in three Kenyan potato varieties. Am Potato J 89:429-437. https://doi.org/10.1007 /s12230-012-9264-1

Struik PC, Wiersema SG (1999). Seed potato technology. Wageningen Academic Publishers, Wageningen Thomas-Sharma S, Abdurahman A, Alli J, Andrade-Piedrad JL, Bao S, Charkowski AO, Crook D, Kadian M, Kromann P, Struik PC, Torrance L, Garrett KA, Forbes G (2016) Seed degeneration in potato: the need for an integrated seed health strategy to mitigate the problem in developing countries. Plant Pathol 65:316. https://doi.org/10.1111/ppa.12439

van der Vlugt RAA, van Raaij H, de Weerdt M, Bergervoet JHW (2015) Multiplex detection of plant pathogens through the Luminex MagPlex bead system. In: Lacomme C (ed) Plant pathology: techniques and protocols, methods in molecular biology, vol 1302, pp 283-299. Springer Science+Business Media, New York. https://doi.org/10.1007/978-1-4939-2620-6_21

VSN International (2016) GenStat for Windows, 18th Edition: VSN International, Hemel Hempstead 